\title{
Cool, alkaline serpentinite formation fluid regime with scarce microbial habitability and possible abiotic synthesis beneath the South Chamorro Seamount
}

\author{
Shinsuke Kawagucci ${ }^{1,5^{*}} \mathbb{D}$, Junichi Miyazaki ${ }^{1}$, Yuki Morono ${ }^{2}$, Jeff S. Seewald ${ }^{3}$, C. Geoff Wheat $^{4}$ and Ken Takai ${ }^{1}$
}

\begin{abstract}
South Chamorro Seamount (SCS) is a blueschist-bearing serpentinite mud volcano in the Mariana forearc. Previous scientific drilling conducted at SCS revealed highly alkaline, sulfate-rich formation fluids resulting from slab-derived fluid upwelling combined with serpentinization both beneath and within the seamount. In the present study, a time-series of ROV dives spanning 1000 days was conducted to collect discharging alkaline fluids from the cased Ocean Drilling Program (ODP) Hole $1200 \mathrm{C}$ (hereafter the CORK fluid). The CORK fluids were analyzed for chemical compositions (including dissolved gas) and microbial community composition/function. Compared to the ODP porewater, the CORK fluids were generally identical in concentration of major ions, with the exception of significant sulfate depletion and enrichment in sulfide, alkalinity, and methane. Microbiological analyses of the CORK fluids revealed little biomass and functional activity, despite habitable temperature conditions. The post-drilling sulfate depletion is likely attributable to sulfate reduction coupled with oxidation of methane (and hydrogen), probably triggered by the drilling and casing operations. Multiple lines of evidence suggest that abiotic organic synthesis associated with serpentinization is the most plausible source of the abundant methane in the CORK fluid. The SCS formation fluid regime presented here may represent the first example on Earth where abiotic syntheses are conspicuous with little biotic processes, despite a condition with sufficient bioavailable energy potentials and temperatures within the habitable range.
\end{abstract}

Keywords: Forearc serpentinite mud volcano, South Chamorro Seamount, Limit of biosphere, Present-days' chemical evolution, Radio-isotope-tracer carbon assimilation estimation

\section{Introduction}

Serpentinization of ultramafic rocks that are the major components of the oceanic lithosphere produces highly reductive fluids, in which transformation of inorganic carbon species to organic matter occur (e.g., McCollom 2013). Serpentinization-associated geofluid systems have been recognized as modern analogs of plausible settings for the origin of primordial life (e.g., Russell et al. 2014) as well as ancient microbial communities (e.g., Takai et al. 2006; Ueda

\footnotetext{
* Correspondence: kawagucci@jamstec.go.jp

'Department of Subsurface Geobiological Analysis and Research (D-SUGAR), Japan Agency for Marine-Earth Science and Technology (JAMSTEC), 2-15 Natsushima-cho, Yokosuka 237-0061, Japan

5 Institute of Geochemistry and Petrology, ETH Zürich, Zürich, Switzerland

Full list of author information is available at the end of the article
}

et al. 2016). Serpentinization-associated geofluid systems, typically characterized by an abundance of $\mathrm{H}_{2}$ and/or highly alkaline fluids, have been discovered at a range of tectonic/ geological settings on the modern Earth where ultramafic rocks encounter water circulation. The most notable examples include slow-spreading mid-oceanic ridges (Charlou et al. 2002; Konn et al. 2015), ocean core complexs (Kelley et al. 2001; Früh-Green et al. 2003), ophiolites (Barnes et al. 1978; Schrenk et al. 2013), coastal springs (Barnes et al. 1967), onshore volcanic hot springs (Homma and Tsukahara, 2008; Suda et al. 2014), inner trench slope along the southern Mariana forearc (Ohara et al. 2012; Okumura et al. 2016a; Onishi et al. 2018), and forearc serpentinite seamounts (Mottl et al. 2004; Fryer, 2011). 
Forearc serpentinite mud volcanoes are formed by extensive serpentinization of the mantle, triggered by the injection of slab-derived fluids into the overlying mantle wedge in a subduction setting. These serpentinization products ascend to form the largest mud volcanoes on Earth (Fryer, 2011). Deep-sea serpentinite mud volcanoes are outstanding settings, compared to other serpentinization-associated geofluid systems (Table 1), for studying abiotic organic syntheses (i.e., present-days' chemical evolution) and for finding the boundary between microbiologically habitable and uninhabitable zones (i.e., limit of life and the biosphere) in natural environments of the Earth. For example, the impermeable mud volcano allows for decreased entrainment of photosynthesisderived organic matter and seawater-derived microbial populations into the internal part of the volcano where pristine mud and fluid ascend from the deep. As such, if we can obtain these pristine fluids contributing to the formation of serpentinite mud volcanoes, then they can be used to address the unique geochemical and microbiological processes associated with these volcanoes.

The South Chamorro Seamount (SCS) is located at the southern end of a serpentinite mud volcano chain in the Mariana forearc, where the Pacific plate subducts beneath the Philippine Sea plate (Fig. 1a). To date, the SCS is the only known location of active blueschist-bearing serpentinite mud volcanism that hosts lush deep-sea chemosynthetic communities sustained by the serpentinite fluid seepage (Fryer and Mottl, 1997). The Ocean Drilling Program (ODP) Leg 195 drilled the summit of the SCS (Site 1200) in 2001 and obtained core samples in order to examine geological and biogeochemical processes associated with subduction (Shipboard Sci. Party 2002). The serpentinite mud porewater, with the exception of taken near the seafloor, exhibited a highly basic $\mathrm{pH}$ of 12.5 and had a composition rich in dissolved sulfate and carbonate. The alkaline porewater chemistry is indicative of slab-derived fluids that had reacted with mantle rocks when ascending through the overlying plate (Fig. 1b), but few studies have investigated the origin of the abundant sulfate in the deep (Mottl et al. 2003, 2004; Hulme et al. 2010). In addition, porewater samples from shallow zones $\sim 20$ mbsf exhibited sulfate depletion and high alkalinity. The chemistry of these shallow fluids has been interpreted to reflect the oxidation of $\mathrm{CH}_{4}$ (and $\mathrm{H}_{2}$ ) derived from the deep by a shallow, subseafloor microbial community including sulfate-reducers (Mottl et al. 2003; Aoyama et al. 2018). However, the gas composition of the porewater could not be accurately determined, since the standard ODP sampling retrieval, handling, and on-board procedures resulted in a significant loss of dissolved gases. Microbiological analyses including phospholipid analysis (Mottl et al. 2003), cell count, and cultivation attempts (Takai et al. 2005) were carried out, but the community structure and potential microbial functions could not be determined.

A cased borehole observatory, the Circulation Obviation Retrofit Kit (CORK), was deployed during the ODP Leg 195 at Hole $1200 \mathrm{C}$ on the SCS (Shipboard Sci. Party 2002; Wheat et al. 2008). When the observatory seal was opened on 20 March 2003, 2 years after its installation, over-pressurized fluids discharged from the CORK outlet

Table 1 Deep-sea serpentinization-associated geofluid fields

\begin{tabular}{|c|c|c|c|c|}
\hline Name of field & South Chamorro Seamount (SCS) & Shinkai Seep Field & Lost City & Rainbow \\
\hline Location & $13^{\circ} 47^{\prime} \mathrm{N}-146^{\circ} 00^{\prime} \mathrm{E}$ & $11^{\circ} 40^{\prime} \mathrm{N}-140^{\circ} 03^{\prime} \mathrm{E}$ & $30^{\circ} 07^{\prime} \mathrm{N}-42^{\circ} 07^{\prime} \mathrm{W}$ & $36^{\circ} 14^{\prime} \mathrm{N}-33^{\circ} 54^{\prime} \mathrm{W}$ \\
\hline Tectonics & Forearc seamount chain & Non-accretionary trench slope & Oceanic core complex, MAR & Non-transform offset, MAR \\
\hline Driving force & Serpentine mud volcanism & (Hydrothermalism?) & Hydrothermalism & Hydrothermalism \\
\hline Fluid source & Slab-derived fluid & Seawater penetration & Seawater penetration & Seawater penetration \\
\hline Approach & ODP, CORK, Dive & Dive & Dive, IODP & Dive \\
\hline Depth (m) & 2960 & 5800 & $700-800$ & 2300 \\
\hline$T \max$ & 2 & - & $>91$ & 365 \\
\hline $\mathrm{pH}$ & 12.5 & (Brucite chimney) & 10.7 & 2.8 \\
\hline $\mathrm{H}_{2}(\mathrm{mM})$ & 0.01 (possibly < 40) & - & 15 & 16 \\
\hline $\mathrm{CH}_{4}(\mathrm{mM})$ & 37 (possibly < 65) & - & 2 & 2.5 \\
\hline Note & $\begin{array}{l}\text { The strongest alkaline } \\
\text { deep-sea geofluid } \\
\text { system so far identified. } \\
\text { See text for details. }\end{array}$ & $\begin{array}{l}\text { Active alkaline fluid seeping } \\
\text { from brucite chimney } \\
\text { surrounded by macrofauna } \\
\text { colony. }\end{array}$ & $\begin{array}{l}\text { Hot alkaline fluid discharging } \\
\text { from tall carbonate chimney, } \\
\text { only identified on the modern } \\
\text { seafloor at this moment. }\end{array}$ & $\begin{array}{l}\text { Black smoker acidic fluid } \\
\text { discharging from sulfide } \\
\text { chimney with abundant } \\
\text { H2. Similar vent sites have } \\
\text { already been found on } \\
\text { the modrern seafloor. }\end{array}$ \\
\hline \multirow[t]{3}{*}{ Ref } & \multirow[t]{3}{*}{ See text } & Ohara et al. 2012 & Kelley et al. 2001 & \multirow[t]{3}{*}{ Charlou et al. 2002} \\
\hline & & Stern et al. 2014 & Früh-Green et al. 2003 & \\
\hline & & $\begin{array}{l}\text { Okumura et al., } 2016 a \\
\text { Onishi et al. } 2018\end{array}$ & Proskurowski et al. 2008 & \\
\hline
\end{tabular}



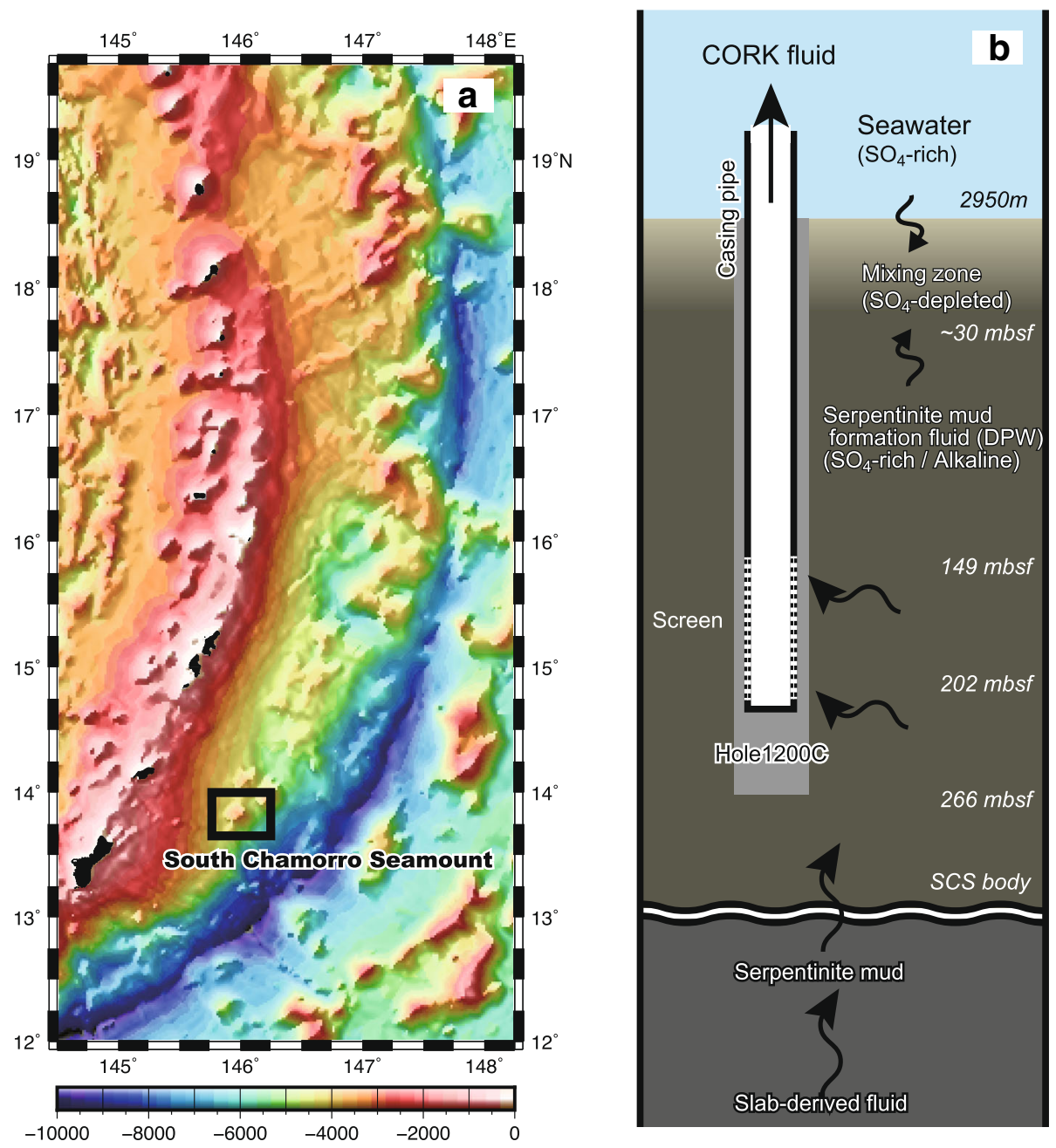

Fig. 1 Topography and schematic illustration of the Mariana forearc and the SCS. a Seafloor topography of the Mariana forearc region. b Schematic illustration of the ODP Hole 1200 C focused in the present study

pipe (this fluid is referred to as the 'CORK fluid' hereafter) at a flow rate of $\sim 0.2 \mathrm{~L} / \mathrm{s}$. The endmember chemical composition of the CORK fluid, estimated from two fluid samples diluted with entrained ambient seawater, was generally similar to those from the porewater samples from deeper zones of the ODP core (Wheat et al. 2008). Although the deep porewater samples obtained during the ODP Leg 195 in 2001 contained abundant sulfate and negligible sulfide, sulfide was present in the highly alkaline ( $\mathrm{pH}$ 12.4) CORK fluid. This difference implies that partial reduction of sulfate to sulfide could occur within the SCS mud volcano before the formation fluid discharged through the cased borehole (Wheat et al. 2008). Discharge from the open borehole continued for 37 days, until the observatory was resealed on 28 April 2003. During the 2003 campaign, however, no gas-tight fluid sampling was conducted despite gas species such as $\mathrm{H}_{2}, \mathrm{CO}$, $\mathrm{CH}_{4}$, and other hydrocarbons are key chemical clues for investigating both abiotic organic synthesis and microbiological habitability/function in an active serpentinite mud volcano.
The present study presents results from four subsequent sample collection campaigns utilizing remotely operated vehicle (ROV) dives with gas-tight fluid samplers (Seewald et al. 2001; Saegusa et al. 2006) and other sampling tools conducted between 2009 and 2012 to collect fresh fluids discharging from the cased borehole of Hole 1200C. The chemistry of the CORK fluid, particularly dissolved gas species, as well as the microbial community composition and function were determined. Carbon and sulfur compositions in the CORK fluids were altered from those from the ODP porewater samples, probably due to changes in the subseafloor hydrological field before and after the scientific drilling event. Analyses of the CORK fluids and the ODP porewater suggested that the sulfate-methane couple likely co-exist in the native SCS formation fluid. However, low biomass and activity were observed environments where physical and chemical conditions, particularly the temperature $\left(\sim 3{ }^{\circ} \mathrm{C}\right)$ and bioavailable energy 
potentials, were suitable for supporting a prosperous microbial community. Multiple lines of evidence, such as low microbial biomass and activity, point to abiotic hydrocarbon synthesis associated with serpentinization occurring beneath the SCS.

\section{Methods/experimental Site description}

In 2001, a series of boreholes were drilled near the seepage sites at the summit of the SCS (ODP Site 1200) (Shipboard Sci. Party 2002). The ODP Hole $1200 \mathrm{C}$ was drilled to $266 \mathrm{mbsf}$ prior to casing and the installation of a CORK device. The final configuration was placed at the base of the casing at $202.8 \mathrm{mbsf}$, providing a screened section from 148.8 mbsf to $202.3 \mathrm{mbsf}$ (Fig. 1b). On 20 March 2003, the CORK monitoring instruments were recovered using the ROV Jason II, and on 28 April 2003 the top of the CORK was resealed by a steel housing holding a downhole pressure sensor (Wheat et al. 2008).

\section{Sampling and analysis \\ Fluid sampling}

CORK fluids were collected for both chemical characterization and analyses of microbial biomass/function during four cruises of the R/V Natsushima with ROV Hyper-Dolphin in January 2009 (NT09-01, HPD\#941-947), May-June 2009 (NT09-07, HPD\#1007-1010), February 2012 (NT12-04, HPD\#1349-1350), and September 2012 (NT12-23, HPD\#1433-1434). On 20 January 2009 (HPD\#941), the valve on the original-type CORK was opened. The discharging fluid (\#941) appeared blackish in coloration, probably due to suspension of sulfide minerals that had accumulated during the past 6 years. The likely source for this blackish fluid is the discharging fluid that occupied the pipe casing when the valve was closed in 2003. After initial samples were collected, the steel plug was replaced with a polyvinyl chloride (PVC) tube and a ball valve. This PVC tube was inserted past the latch holes in the CORK body, sealing the borehole from the bottom seawater. Thus, fluids collected from the top of the CORK can be considered pristine CORK fluids with minimal or no entrainment of the bottom seawater (Wheat et al. 2008). Fluid collected during subsequent dives appeared to be colorless and clear at the mouth of the CORK but the coloration changed to whitish after venting, most likely due to the precipitation of brucite from seawater-derived $\mathrm{Mg}^{2+}$ and CORK fluid-derived $\mathrm{OH}^{-}$.

CORK fluids were collected using several types of fluid samplers, including WHATS, Bag, and Isobaric Gas-Tight (IGT) samplers (Seewald et al. 2001; Saegusa et al. 2006). The whitish fluids were also collected into pre-evacuated stainless-steel bottles with radio-isotope-labeled tracers for metabolic activity measurements (see below). The inlet nozzles for WHATS and Bag samplers were inserted as deep as possible into the borehole in order to minimize seawater contamination. For fluids collected using IGT samplers, a polycarbonate reservoir was attached to the CORK ball valve. The reservoir was flushed with several volumes of CORK fluid before the IGT sampler snorkel was inserted into the reservoir through a rubber diaphragm to collect pristine CORK fluid without seawater entrainment.

A special sampling device, named the "Deep Sampler," was also used during cruises NT12-04 and NT12-23 to collect fluid within the borehole at subseafloor depths where the screened casing is positioned (Fig. 2). The Deep Sampler consisted of a $100 \mathrm{~mL}$ gas-tight and pressure-preserved titanium bottle and a valve connected to a winch on the seafloor with a rope. The open titanium bottle-chamber-valve units were lowered to a depth of $179 \mathrm{mbsf}$ within the depth range of the screens, before a messenger weight was dropped from the seafloor to slide the bottle unit to the chamber-valve unit for fluid sampling (a few seconds to $10 \mathrm{~s}$ time) and in the end sealing the fluid in two of the chambers (Fig. 2). The temperature was monitored during fluid sampling, which increased from $\sim 1.7{ }^{\circ} \mathrm{C}$ at the seafloor to $3.3^{\circ} \mathrm{C}$ at $170 \mathrm{~m}$ below the seafloor (thermal gradient of $9.4^{\circ} \mathrm{C} / \mathrm{km}$ ). Samples collected by the Deep Sampler and the other samplers did not show significant differences in their chemical composition, implying that fluid alteration and seawater contamination during the $12 \mathrm{~h}$ ascent through the cased hole (Wheat et al. 2008) was negligible.

\section{Geochemistry}

Immediately upon recovery of the ROV, fluid samples were subsampled for liquid and gas analyses. For liquid phase analysis, the fluid sample was withdrawn into disposable plastic syringes for filtration, and then introduced into acid-washed HDPE bottles and glass vials. Shipboard measurements included $\mathrm{pH}$, alkalinity, chlorinity, and hydrogen sulfide. Shore-based analyses with devices such as ion chromatography (IC), inductively coupled plasma atomic emission spectrometry (ICP-AES), and ICP mass spectrometry (ICP-MS) were conducted using techniques similar to those carried out for the ODP 1200 porewater samples (e.g., Mottl et al. 2003, 2004), thus minimizing analytical biases among these studies. Dissolved gas extraction from fluid samples collected with the WHATS sampler was conducted using previously reported techniques (e.g., Kawagucci et al. 2016; Miyazaki et al. 2017). To extract the total inorganic carbon (mainly $\mathrm{CO}_{3}{ }^{2-}$ ) as $\mathrm{CO}_{2}$ for abundance and isotope analyses, the fluid sample was acidified with $\sim 3 \mathrm{~g}$ of solid sulfamic acid $\left(\mathrm{H}_{3} \mathrm{NSO}_{3}\right)$ in the extraction line. While the total gas content was determined barometrically during the gas extraction, the relative abundance of $\mathrm{H}_{2}, \mathrm{CH}_{4}, \mathrm{CO}, \mathrm{CO}_{2}, \mathrm{C}_{2} \mathrm{H}_{6}$, and $\mathrm{C}_{3} \mathrm{H}_{8}$ in the whole gas phase were determined by gas chromatography using a helium ionization detector. The 

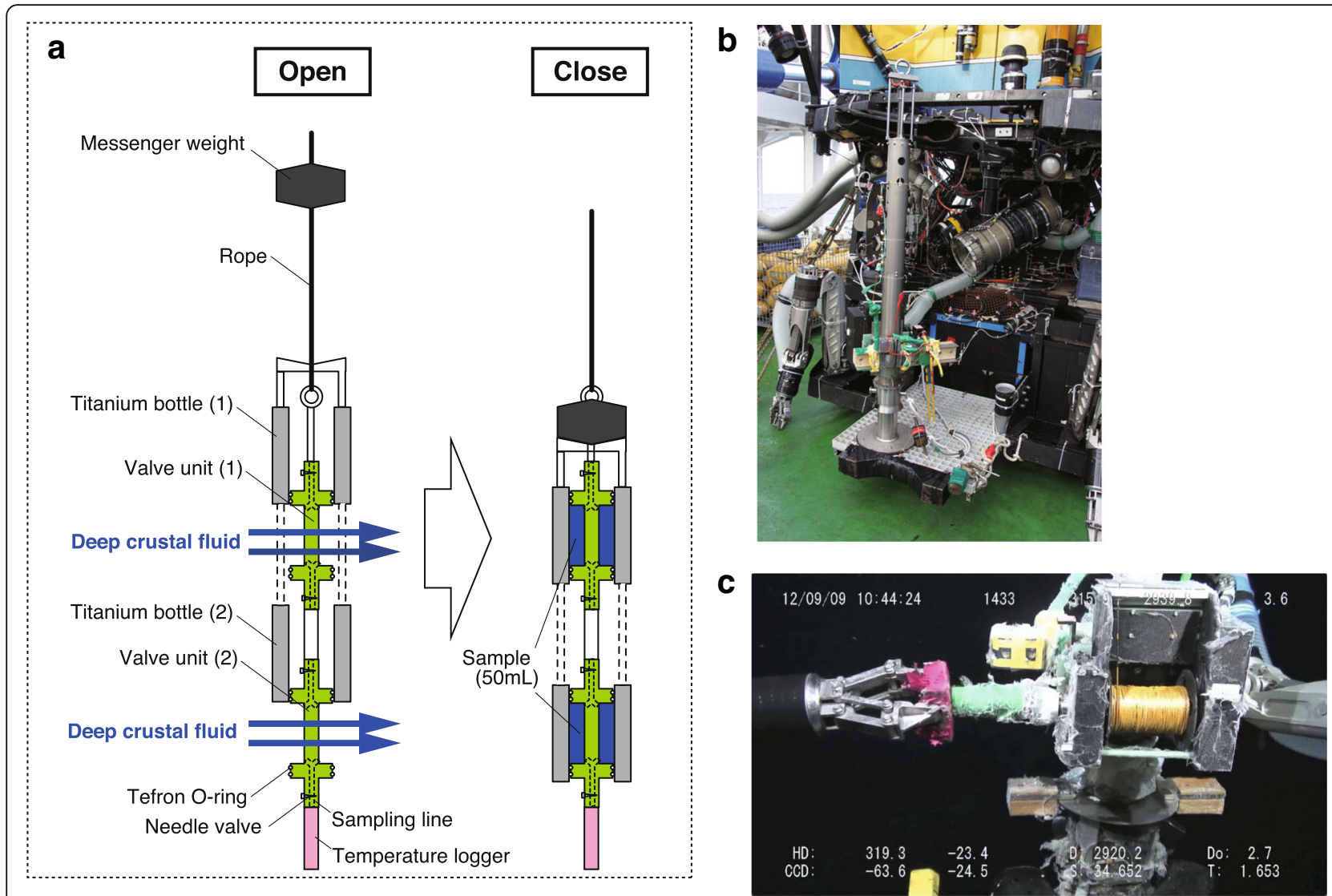

Fig. 2 A schematic illustration and photographs of the "Deep Sampler" used for CORK fluid sampling. a The open titanium bottle, chamber, and valve units were lowered to the screened depths $(170 \mathrm{mbs}$ ) through the cased hole. Then, a messenger weight was dropped from the seafloor along the rope, resulting in closing the bottle unit to the chamber-valve unit for fluid sampling. $\mathbf{b}$ A photograph showing the Deep Sampler being prepared in the payload of the ROV Hyper-Dolphin. c A photograph showing the on-site operation of the Deep Sampler from $170 \mathrm{mbsf}$ by manipulation of reeling in the support line

stable isotopic compositions of $\mathrm{H}_{2}, \mathrm{CH}_{4}, \mathrm{CO}_{2}$, and $\mathrm{C}_{2} \mathrm{H}_{6}$ were determined using the continuous flow method with DELTA XP Advantage and/or MAT253 Isotope Ratio Mass Spectrometer (Thermo Fisher Scientific) in JAMSTEC in accordance with previously published techniques (e.g., Okumura et al. 2016b; Shibuya et al. 2017). In the present study, isotope ratio and isotope fractionation between two molecules is represented by conventional $\delta$ and $\alpha$ notations as $\delta^{13} \mathrm{C}_{\mathrm{A}}=\left[\left({ }^{13} \mathrm{C}_{\mathrm{A}} /{ }^{12} \mathrm{C}_{\mathrm{A}}\right) /\left({ }^{13} \mathrm{C}_{\mathrm{STD}} /{ }^{12} \mathrm{C}_{\mathrm{STD}}\right)-1\right]$ (presented in permil scale) and $\alpha C_{A-B}=\left(\delta^{13} C_{A}+1\right) /\left(\delta^{13} C_{B}+1\right)$. Samples collected using IGT samplers were analyzed at sea for dissolved $\mathrm{H}_{2}$ and $\mathrm{CH}_{4}$ using gas chromatography with thermal conductivity detection, following headspace extraction.

\section{Microbiology}

During cruises NT09-01 and NT09-07, microbial cells in subsampled fluids $(110-370 \mathrm{~mL})$ were collected on-board the ship onto $0.2 \mu \mathrm{m}$ pore $47 \mathrm{~mm}$ polycarbonate membranes (K020A047A, ADVANTEC, Tokyo Japan) placed in line holder (KS-47, ADVANTEC, Tokyo Japan). The cells were fixed by placing a fixation solution
(2\% paraformaldehyde-PBS solution) onto the membranes and kept overnight at $4{ }^{\circ} \mathrm{C}$. Then, the membrane was washed by PBS, partially dried by placing on filter paper, and kept at $-20{ }^{\circ} \mathrm{C}$ for later cell counting. The fluid sample taken on the cruise NT12-23 was immediately fixed by adding $1 / 5$ volume of $10 \%$ Formalin Neutral Buffer Solution (Wako, Japan) and stored at $4{ }^{\circ} \mathrm{C}$ until further processing. Since white precipitates formed in fixed fluid samplers during storage at $4{ }^{\circ} \mathrm{C}$, separation of cells was conducted according to Morono et al. (2013), with some modifications. In brief, for 3-15 mL of fixed solution, 1/10 volume each of detergent mix (100 mM EDTA, $100 \mathrm{mM}$ sodium pyrophosphate, 1\% $[v / v]$ Tween 80$)$ and methanol were added and treated in an ultrasonic bath (Bioruptor UCD-250, Cosmo Bio, Tokyo Japan) at $160 \mathrm{~W}$ with cycles of $1 \mathrm{~min} \mathrm{ON}$ and $1 \mathrm{~min}$ OFF for $20 \mathrm{~min}$. The treated samples were then carefully layered onto step gradient heavy density solution composed of $67 \%(\mathrm{w} / \mathrm{w})$ sodium polytungstate (SPT1, SOMETU, Berlin, Germany), 80\%, 50\%, and 30\% $(w / v)$ Nycodenz and centrifuged for $120 \mathrm{~min}$ at $10,000 \times g$ 
at $25{ }^{\circ} \mathrm{C}$. Light density upper layers were recovered, and $10 \%$ of the suspension was passed through a $0.2 \mu \mathrm{m}$ pore $25 \mathrm{~mm}$ polycarbonate membrane to trap microbial cells. The filters were stored at $-20{ }^{\circ} \mathrm{C}$ until counting. From Bag sampler (NT09-01) and Deep Sampler (NT12-23), about $10 \mathrm{~L}$ and $40 \mathrm{~mL}$ of fluids, respectively, were filtered with $0.22 \mu \mathrm{m}$-pore-sized cellulose acetate filters to collect microbial cells. Filters were stored at $-80{ }^{\circ} \mathrm{C}$ for microbial 16S rRNA gene clone sequencing analysis.

Microbial cell densities in CORK fluid samples were determined using a semi-automated cell counting system (Morono et al. 2009). In brief, trapped and fixed cells collected on a polycarbonate membrane were stained with SYBR green I staining solution $(1 / 40[v / v]$ SYBR Green I in TE buffer). The stained filter was washed with $1 \mathrm{ml}$ of TE buffer and then mounted on a glass microscope slide with 3-5 $\mu \mathrm{L}$ of mounting solution (2:1 mixture of VECTASHIELD mounting medium H-1000 and TE buffer). Microscopic fluorescence image acquisition (at 525/36 nm [center wavelength/bandwidth] and $605 / 52 \mathrm{~nm}$ by $490 \mathrm{~nm}$ excitation) was performed automatically using a fluorescence microscope equipped with an automatic slide handler (Morono and Inagaki, 2010). The resulting images were analyzed using the macro of the Metamorph software (Molecular Devices, CA, USA) to identify and count microbial cells on the membrane.

Phylotype composition of $16 \mathrm{~S}$ rRNA genes were determined using clone sequencing in the laboratory based on a previously published methodology (Nunoura et al. 2012) with some modifications. DNA assemblages were extracted from microbial cells on filters using the UltraClean Soil DNA Isolation Kit (MO BIO Laboratories, Carlsbad, CA, USA). Amplification of 16S rRNA genes from the extracted DNA assemblage was accomplished by a Polymerase Chain Reaction (PCR) method with LA Taq polymerase (Takara Bio, Otsu, Japan) using a primer set of 530F/907R. The amplified 16S rRNA gene fragments were applied to electrophoresis and cleaned up with a QIA quick Gel extraction Kit (QIAGEN, Valencia, CA, USA). The 16S rRNA gene clone libraries were constructed using the TA cloning kit (Invitrogen, Carlsbad, CA, USA). The nucleotide sequences of randomly selected clones were determined with a BigDye Terminator version 3.1 sequencing kit (Applied Biosystems, Foster City, CA, USA) using M13M4 (5'-GTTTTCCCAGTCACGAC-3') and M13RV (5' ${ }^{\prime}$-TGTGGAATTGTGAGCGG-3') primers on an ABI PRISM 3730xl Genetic analyzer (Applied Biosystems, Foster City, CA, USA). The sequences were assembled with Sequencher Ver. 4.8 software (Gene Code Corporation, Ann Arbor, MI, USA). The most similar reference sequences were retrieved from RDP and the GenBank database. The nucleotide sequences obtained were deposited to DDBJ (DNA data bank of Japan) with accession numbers LC279286-LC279362.

\section{Radio isotope tracer experiment to estimate potential metabolic rates}

Potential activities of microbial assimilations of bicarbonate, methane, carbon monoxide, formate, acetate, and leucine (autotrophic, methanotrophic, carboxydotrophic, and heterotrophic activities, respectively) were estimated by radio isotope tracer experiment using CORK fluid samples obtained during the expeditions NT09-01 and NT09-07. The CORK fluid was collected in multiple evacuated $150 \mathrm{~mL}$ stainless-steel bottles, each connected to a three-way valve and a sampling nozzle. All surfaces of the bottle, valve, and nozzle were treated with SilicoNert coating (Silcotek Corporation, Bellefonte, PA, USA) to avoid direct contact between the fluid and stainless steel. The sampling was conducted in duplicates for each of the radio isotope tracers. Prior to the seafloor sampling by the ROV, each of the radio-isotope-tracers $\quad\left(\mathrm{NaH}^{14} \mathrm{CO}_{3},{ }^{14} \mathrm{CH}_{4},{ }^{14} \mathrm{CO}\right.$, $\mathrm{H}^{14} \mathrm{COONa},{ }^{14} \mathrm{CH}_{3}{ }^{14} \mathrm{COONa},{ }^{14} \mathrm{C}$-leucine) was placed in two bottles (with and without formaldehyde at a final concentration of $4 \%)$ as solution $\left(\mathrm{NaH}^{14} \mathrm{CO}_{3}\right.$, $\mathrm{H}^{14} \mathrm{COONa},{ }^{14} \mathrm{CH}_{3}{ }^{14} \mathrm{COONa},{ }^{14} \mathrm{C}$-leusin and formaldehyde) or gas $\left({ }^{14} \mathrm{CH}_{4}\right.$ and $\left.{ }^{14} \mathrm{CO}\right)$ in sealed glass ampoules. The final radioactivity level was $0.25 \mathrm{MBq}$ per bottle. In order to assess the methanotrophic activity, three treatments were used: (i) only ${ }^{14} \mathrm{CH}_{4}$ added, (ii) ${ }^{14} \mathrm{CH}_{4}$ and $\mathrm{O}_{2}$ (a final concentration of $40 \mu \mathrm{M} \mathrm{O}$ ) added, and (iii) ${ }^{14} \mathrm{CH}_{4}$ and $\mathrm{Na}_{2} \mathrm{SO}_{4}$ and $\mathrm{Na}_{2} \mathrm{~S}$ (final concentrations of $10 \mathrm{mM}$ and $0.5 \mathrm{mM}$, respectively) added. The additional $\mathrm{O}_{2}$ or $\mathrm{Na}_{2} \mathrm{SO}_{4}$ and $\mathrm{Na}_{2} \mathrm{~S}$ were introduced either as a gas or as a solution sealed in a glass ampoule. The final concentrations of ${ }^{14} \mathrm{C}$-labeled tracers in the bottles were estimated to be about $0.1 \mathrm{mM}, 0.4 \mathrm{mM}, 0.4 \mathrm{mM}, 0.1 \mathrm{mM}$, $0.1 \mathrm{mM}$, and $0.1 \mathrm{mM}$ for bicarbonate, methane, carbon monoxide, formate, acetate, and leucine, respectively. After placing the radio isotope tracer into the bottle with three stainless-steel balls, the bottle was evacuated with a vacuum pump. The bottle was then sealed and shaken, which resulted in the stainless-steel balls rapturing the glass ampoules containing the radio-isotope-tracers and formaldehyde. At the seafloor, the sampling nozzle of the radio-isotope-tracer sampler was placed in the discharging CORK fluid and sufficiently flushed. Fluid sample was collected by opening and closing the valve with the ROV manipulator. Immediately after recovery of the ROV, sample bottles were incubated at $4{ }^{\circ} \mathrm{C}$ for 49 123 days until measurement in a shore-based laboratory. The bottles containing $4 \%$ formaldehyde were used as negative controls (i.e., with no microbial activity).

As a positive control for methane assimilation, stationary phase cells of a gammaproteobacterial methanotroph, Methylomarinum vadi, (Hirayama et al. 2013) were incubated in its medium (Hirayama et al. 2007) at $37^{\circ} \mathrm{C}$ for 1 day under the same substrate condition $(0.4 \mathrm{mM})$ as the 
aerobic methanotrophic activity measurement, as described above. The cell density of $M$. vadi was adjusted to be $2.0 \times 10^{6}$ cells in the bottle $\left(1.3 \times 10^{4}\right.$ cells $\left./ \mathrm{mL}\right)$. As a positive control for bicarbonate assimilation, natural deep-sea diffusing hydrothermal fluid (average fluid temperature of $57^{\circ} \mathrm{C}$ ) from the Iheya North field (Takai et al. 2004), sampled in July-August 2010 using the same method described in previous sections of the present study, was incubated at $60{ }^{\circ} \mathrm{C}$ for 5 days under the same substrate condition $(10 \mathrm{mM})$. The cell density of microbial community in the CORK fluid was $1.0 \times 10^{2}$ cells $/ \mathrm{mL}$, thus each incubation bottle contained $1.5 \times 10^{4}$ cells.

CORK fluid samples (approx. $150 \mathrm{~mL}$ ) were incubated with radio-isotope-tracers for $49-123$ days at $4{ }^{\circ} \mathrm{C}$ and then depressurized and filtered with a $0.22 \mu \mathrm{m}$-pore-sized cellulose acetate filters. Each filter was fixed with $10 \mathrm{~mL}$ of $4 \%(w / v)$ paraformaldehyde/PBS solution ( $\mathrm{pH} 7.2)$ for $30 \mathrm{~min}$, then thoroughly rinsed with filter-sterilized $0.1 \mathrm{M} \mathrm{HCl}$ in $3 \%(w / v) \mathrm{NaCl}$ solution to remove carbonate precipitates. The filter was slurried in $20 \mathrm{~mL}$ of Hionic Flour cocktail (PerkinElmer, Waltham, MA, USA), and the radioactivity measured using a Tri Carb 2910TR liquid scintillation counter (PerkinElmer, Waltham, MA, USA). The assimilation rates of the tracers were calculated from concentrations and radio-isotope ratios given as the substrate in the initial state and the radio-isotope abundance of the filter. Blanks were evaluated by non-labeled batch incubation and used for calibration.

\section{Results}

\section{$\mathrm{pH}$, chlorinity, and major and minor ions}

Concentrations of major and minor ions in the fluids were nearly identical in all samples, regardless of the sampling device used for collection (Additional file 1: Table S1). The chemistry of conservative components in CORK fluids were quite similar to those of deep (> $20 \mathrm{mbsf}$ ) porewater samples (DPW) obtained from the ODP Holes 1200 (Additional file 1: Table S1). For example, the fluid chlorinity $(503-510 \mathrm{mmol} / \mathrm{kg})$ of CORK fluids was distinguishable from seawater level $(540 \mathrm{mmol} / \mathrm{kg}$ ) and identical to those of the DPW (510 $\pm 5 \mathrm{mmol} / \mathrm{kg}$ ) (Fig. 3a). CORK fluids ranged from 12.1 to 12.3 in $\mathrm{pH}$ values, which were slightly lower than the highest $\mathrm{pH}$ of $12.5 \pm 0.1$ in the DPW (Fig. 3b). Slight differences between CORK fluids and the DPW in alkali metals $(\mathrm{K}, \mathrm{Li}, \mathrm{Rb})$ (Additional file 1: Table S1) have been interpreted to be due to sampling artifacts during the core recovery and porewater extraction of the ODP serpentinite samples (de Lange et al. 1992; Wheat et al. 2008). Alkali earth metals ( $\mathrm{Mg}, \mathrm{Ca}, \mathrm{Sr}$ ) were depleted in the CORK fluids, as well as the DPWs (Fig. 3c). Seawater entrainment during the seafloor sampling cannot be evaluated precisely, because any entrainment of $\mathrm{Mg}$ from seawater would be precipitated immediately as brucite. Nevertheless, the nearly identical and high concentrations of B, for example (Fig. 3d), are consistent with a scenario where mixing with ambient seawater during sample collection was minimal. Combined, these data are consistent with the CORK fluids being derived from a deep-sourced formation fluid that flowed into the borehole through screens located at a depth range of 149 and 202 mbsf.

\section{Sulfate, alkalinity, sulfide, and ammonium}

Sulfate concentrations in the discharging CORK fluids were $0.4-1.7 \mathrm{mM}$, significantly lower than the concentration of $28 \mathrm{mmol} / \mathrm{kg}$ in the DPW and the seawater (Fig. 3e). The alkalinities of these fluids were much higher $(119-126 \mathrm{meq} / \mathrm{kg})$ than in the DPW $(62 \mathrm{meq} / \mathrm{kg})$ (Fig. 3f) and comparable to the value estimated from the previous CORK fluid observation $(104 \mathrm{meq} / \mathrm{kg}$ ) (Wheat et al. 2008). Both sulfate concentration and alkalinity in the CORK fluid from Dive \#941 were in-between values of the DPW and other CORK fluids. These results point to a stoichiometry of 2 meq increase of alkalinity with $1 \mathrm{mmol}$ decrease of sulfate in the CORK fluids when compared to the DPW (Fig. 4a). Dissolved reduced sulfur (sulfide) in CORK fluids was significant despite negligible sulfide concentrations detected in the DPW and showed a temporal decreasing trend: $\sim 24 \mathrm{mM}$ in 10 days, $21 \mathrm{mM}$ in 4 months, and $\sim 10 \mathrm{mM}$ in more than 36 months (Fig. 3g). The sum of sulfate and sulfide concentrations in the CORK fluids were not higher than $28 \mathrm{mM}$, suggesting quantitative conversion in addition to the removal of dissolved sulfur to the solid phase (Fig. 4b). Ammonium concentrations were identical at 0.2-0.3 $\mathrm{mM}$ among all CORK fluids and the DPW (Additional file 1: Table S1). The highly variable alkalinity with the constantly low ammonium concentrations implies that the alkalinity variation do not result from the decomposition of sedimentary Redfield organic matter (Redfield, 1958) but from that of N-depleted organic carbon such as $\mathrm{CH}_{4}$.

\section{Gas composition and stable isotopes}

Methane concentrations in the CORK fluids were variable between $5.5-6.1 \mathrm{mM}$ in 10 days, $9.2-37.8 \mathrm{mM}$ in 4 months, and $16.1-37.4 \mathrm{mM}$ in more than 36 months after the valve was opened, respectively (Fig. $3 \mathrm{~h}$ ). $\mathrm{CH}_{4}$ concentrations in CORK fluids were significantly higher than those observed in the DPW $(<2 \mathrm{mM})$. The differences strongly suggest that $\mathrm{CH}_{4}$ was degassed from the DPW during core recovery and sample processing during the ODP Leg 195 (Mottl et al. 2003). This claim is consistent with a solubility-controlled $\mathrm{CH}_{4}$ concentration of $\sim 2 \mathrm{mM}$ at room pressure and temperature (Wiesenburg and Guinasso jr, 1979). The $\mathrm{CH}_{4}$ concentrations in CORK fluids are the highest among any deep-sea serpentinization-associated geofluid systems 

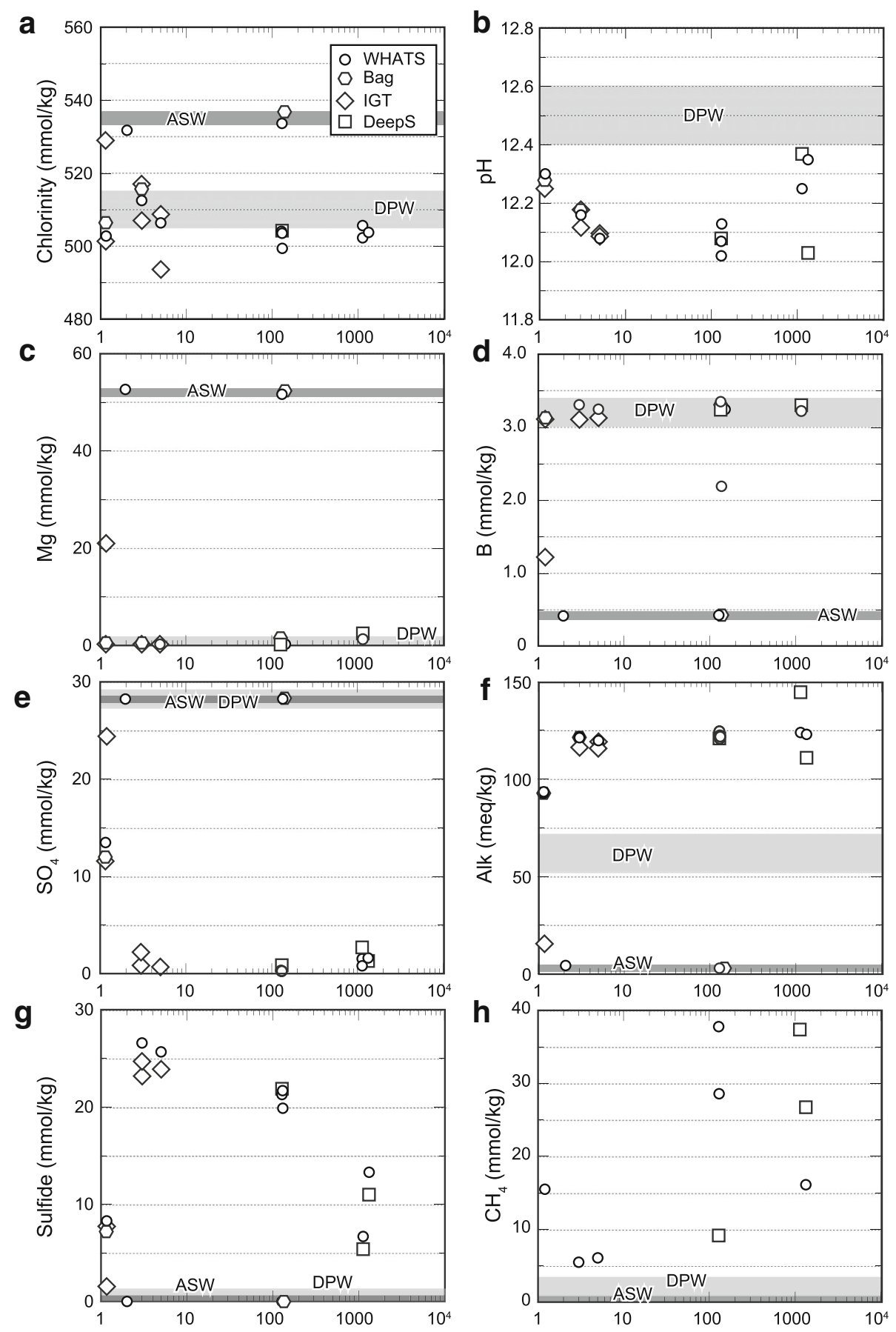

Days after the valve opened

Fig. 3 Time-series of fluid chemistry since the valve opening. Light and dark gray bars represent the deep part of the ODP porewater at Site 1200 (DPW) (Mottl et al. 2003) and ambient seawater (ASW) composition, respectively. Each symbol represents a type of fluid sampler used: WHATS (circle), Bag (hexagon), IGT (diamond), and Deep Sampler (square). Time ( $x$ axis) is in logarithmic scale

reported to date (<2 mM) (Charlou et al. 2002; Kumagai et al. 2008; Schrenk et al. 2013; Konn et al. 2015; McDermott et al. 2015; Seyfried et al. 2011). Ethane concentrations were also variable between 0.01 and $0.23 \mathrm{mM}$. Relative abundances of $\mathrm{CH}_{4}$ to $\mathrm{C}_{2} \mathrm{H}_{6}\left(\mathrm{C}_{1} / \mathrm{C}_{2}\right)$ were $\sim 27$ in 1 day,
216-3178 in 10 days to 4 months, and 231-285 in 36 months after the valve opening. Molecular hydrogen concentrations in the CORK fluids ranged between 0.003 and $0.107 \mathrm{mM}$ and were the lowest among values repoted from deep-sea serpentinization-associated geofluid systems 

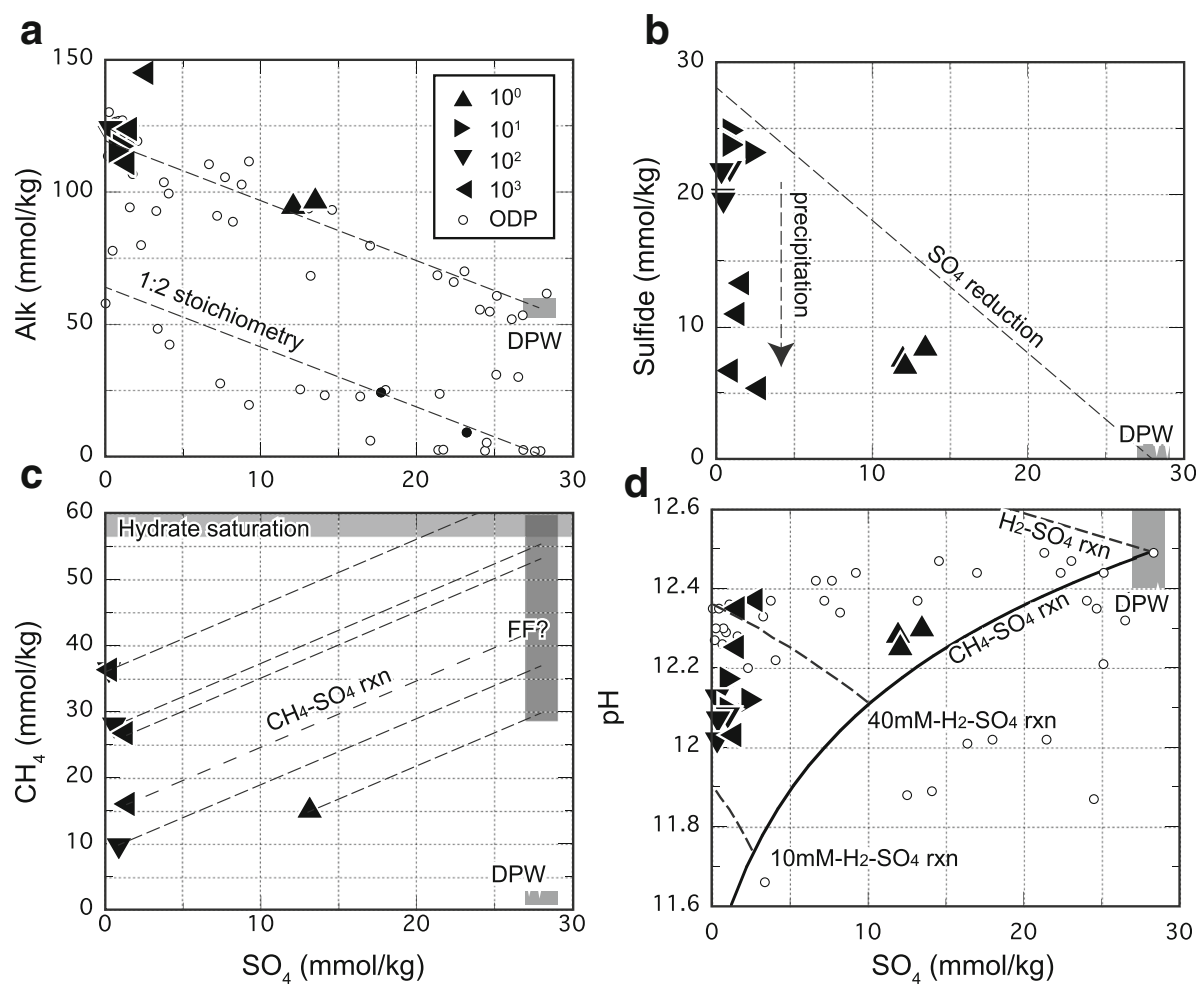

Fig. 4 Relationships between sulfate and alkalinity, sulfide, $\mathrm{CH}_{4}$, and $\mathrm{pH}$. Filled triangles represent the CORK fluids from the present study, classified by the number of days after the valve was opened. Filled and open circles represent the CORK fluid observed in 2003 and DPW, respectively, shown for comparison. Light gray zones represent the estimated endmember formation fluid composition of the ODP porewater (DPW) or a solubility of $\mathrm{CH}_{4}$ hydrate clathrate under the SCS condition (only shown in panel c). Broken lines in panels (a), (c), and (d) represent ideal changes in the chemical composition based on selected reactions. The dark gray zone in panel (c) represents possible $\mathrm{CH}_{4}$ concentrations of the SCS formation fluid (FF) without post-drilling alteration. The solid curve in panel (b) represents sulfate consumption through $\mathrm{CH}_{4}-\mathrm{SO}_{4}$ reaction from the porewater-based endmember. Broken curves in panel (b) represent sulfate consumption with 10,40 , and $>112 \mathrm{mM}$ of $\mathrm{H}_{2}$, in addition to the $\mathrm{CH}_{4}-\mathrm{SO}_{4}$ reaction

to date (>1 mM) (Charlou et al. 2002; Kumagai et al. 2008; Schrenk et al. 2013; Konn et al. 2015; McDermott et al. 2015; Seyfried et al. 2011). Relative abundances of $\mathrm{CH}_{4}$ to $\mathrm{H}_{2}$ $\left(\mathrm{CH}_{4} / \mathrm{H}_{2}\right)$ ranged from 333 to 1350 for the CORK fluids. This $\mathrm{CH}_{4} / \mathrm{H}_{2}$ ratio is higher than those of seafloor geofluids associated with serpentinization in other geologic settings $(<1)$. Total dissolved inorganic carbon (DIC), extracted and quantified as $\mathrm{CO}_{2}$, ranged from 17 to $51 \mathrm{mM}$, which is consistent with the estimated carbonate alkalinity of the DPW (45 meq/kg: Mottl et al. 2003). The potentially insufficient acidification of DIC samples prior to the gas analysis may result in the underestimation of DIC concentrations in the CORK fluids.

Carbon and hydrogen isotopic ratios of methane $\left(\delta^{13} \mathrm{C}_{\mathrm{C} 1}\right.$ and $\left.\delta \mathrm{D}_{\mathrm{C} 1}\right)$ and ethane $\left(\delta^{13} \mathrm{C}_{\mathrm{C} 2}\right.$ and $\left.\delta \mathrm{D}_{\mathrm{C} 2}\right)$ were uniform among the CORK fluids, with values of $-37 \%$, $117 \%$, $-11 \%$, and $-86 \%$, respectively, regardless of concentration (Additional file 1: Table S1). The $\delta^{13} C_{C 1}$ value of CORK fluids is significantly lower than other serpentinization-associated hydrothermal fluids reported to date $(>-18 \%$ ) (Fig. 5a) (Charlou et al. 2002; Kumagai et al. 2008; Schrenk et al. 2013; Konn et al. 2015; McDermott et al. 2015). The higher $\delta^{13} C_{C 1}$ value in the shallow ODP porewater observed previously $(-11 \pm 5 \%$ at 15 mbsf: Mottl et al. 2003) is significantly different from the CORK fluid and is likely attributed to ${ }^{13} \mathrm{C}$ enrichment in the remnant $\mathrm{CH}_{4}$ due to microbial methanotrophic activity in the fluid-seawater interface. The $\delta^{13} \mathrm{C}_{\mathrm{C} 2}$ value of the CORK fluids falls into the range of $\delta^{13} \mathrm{C}_{\mathrm{C} 2}$ values observed in serpentinization-associated hydrothermal fluids $\left(-14 \%\right.$ to $-2 \%$ ) (Konn et al. 2015). The $\delta D_{\mathrm{C} 2}$ value of the CORK fluids $(-86 \%)$ is higher than that of the Lost City field $(\sim-150 \%)$ (Fig. 5b). Total DIC of the CORK fluids showed $\delta^{13} C_{\text {DIC }}$ values of $-2.9 \%$ to $+1.4 \%$. The $\delta^{13} \mathrm{C}_{\text {DIC }}$ values close to $+0 \%$ o suggest that the DIC originates from sedimentary carbonate $(\sim+0 \%)$ rather than photosynthesis-based organic matter $(\sim-25 \%$ ) (Sano and Marty 1995). Hydrogen isotope ratios of $\mathrm{H}_{2}\left(\delta \mathrm{D}_{\mathrm{H} 2}\right)$ were $-787 \%$ to $-761 \%$, which can be attributed to $\mathrm{H}_{2}-\mathrm{H}_{2} \mathrm{O}$ hydrogen isotope equilibrium at an in situ temperature of $2{ }^{\circ} \mathrm{C}$ (Horibe and Craig, 1995) when using the $\delta \mathrm{D}_{\mathrm{H} 2 \mathrm{O}}$ value of $+12 \%$ observed in the DPW (Mottl et al. 2003). 


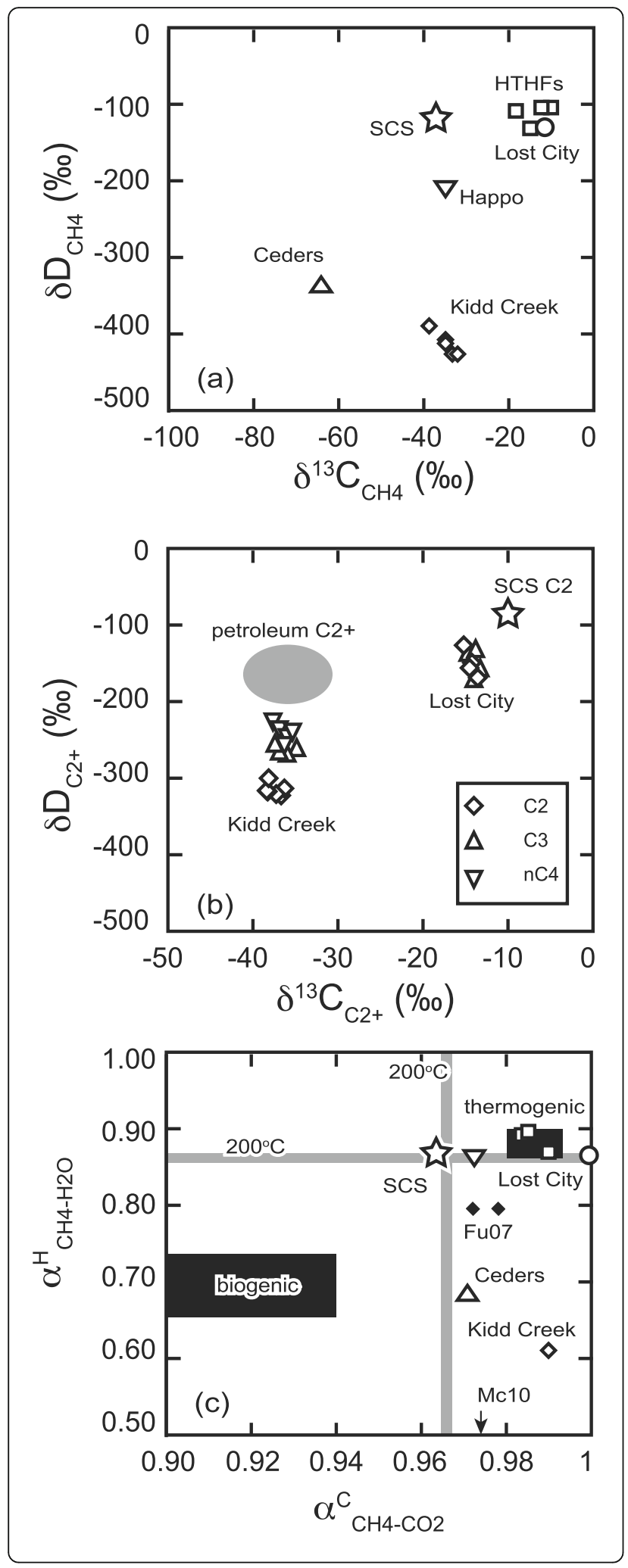

Fig. 5 Stable isotope composition of $\mathrm{CH}_{4}, \mathrm{C}_{2} \mathrm{H}_{6}$, and the relevant molecules. Open and filled symbols, respectively, represent data from observations of hydrocarbon-enriched geofluid systems and experiments simulating methanogenesis. Data sources are following: high-temperature hydrothermal fluids (Konn et al. 2015; Kawagucci et al. 2016 and references therein), Lost City (Proskurowski et al. 2006; 2008), Happo (Suda et al. 2014), The Ceders (Wang et al. 2015), Kidd Creek (Sherwood-Lollar et al. 2002), petroleum field (Burruss and Laughrey 2010), magnetite experiments (Fu et al. 2007), Fe experiment (McCollom et al. 2010), thermogenic experiment (Seewald et al. 1994) (assuming the $\mathrm{CH}_{4}-\mathrm{H}_{2} \mathrm{O}$ isotope equilibrium), and microbial incubation (Okumura et al. 2016b)

\section{Microbial cell density}

Microbial cell densities of CORK fluids were estimated by epifluorescence microscopy (Table 2). In the blackish fluid discharging at the time when the valve was first opened (Dive \#941), we measured a microbial cell density of $2.0 \times 10^{3}$ cells $/ \mathrm{mL}$. This is much lower than the cell density in the ambient seawater $\left(2.2 \times 10^{4}\right.$ cells $\left./ \mathrm{mL}\right)$ sampled during the same cruise (Table 2). The microbial cell densities in the clear CORK fluid sampled 4 days and 4 months after the valve opening decreased to 4.4$6.6 \times 10^{2}$ and $1.0 \times 10^{2}$ cells $/ \mathrm{mL}$, respectively (Table 2 ). These results suggest that, before the valve opening, certain microbial communities maintained their populations and functions in some of the microhabitats in the stagnant CORK fluid of the sealed borehole and wellhead structures. Such local microbial populations in the stagnant fluid system were flushed out by the newly created discharging fluid flow after the valve was opened. After more than 36 months, however, the microbial cell densities in the CORK fluid were $4.1-7.6 \times 10^{3}$ cells $/ \mathrm{mL}$ (Table 2).

\section{Microbial phylotype compositions}

The 16S rRNA gene phylotype compositions of microbial communities in CORK fluid samples at the time that the valve was opened, 3 days later, and 45 months later were examined. In total 89,88 , and 44 clones were sequenced for the microbial communities in the CORK fluid samples at the time of valve opening, 3 days later, and 45 months later, respectively (Fig. 6). The phylotype compositions were significantly different among the fluid samples.

In the blackish discharging fluid $\left(2.0 \times 10^{3}\right.$ cells $/ \mathrm{mL}$ of microbial cell density), the gamma-proteobacterial phylotypes dominated the clone library and consisted almost entirely of a single phylotype closely related with Methylobactor, a methanotrophic endosymbiont of Bathymodiolus mussels living in the SCS seepage sites (Fig. 6). The alpha-proteobacterial and actinobacterial phylotypes were the second most abundant groups in the library. Other components were phylotypes of Betaproteobacteria and Firmicutes. In the 
Table 2 Microbial cell density in the CORK fluid and ambient seawater samples

\begin{tabular}{lllll}
\hline Cruise ID & HPD dive\# & Time after valve opening & Sample type & Cell count $\left(\right.$ cells ml $\left.^{-1}\right)$ \\
\hline NT09-01 & 941 & 0 day & Bag & 2000 \\
NT09-01 & 943 & 2 days & Bag & 440 \\
& 943 & (ambient seawater) & Bag & 22,000 \\
& 945 & 4 days & Bag & 660 \\
NT09-07 & 1007 & 5 months & Bag & 101 \\
& 1009 & 5 months & Bag & 139 \\
NT12-04 & 1349 & 45 months & WHATS & 7600 \\
& 1350 & 45 months & Deep sampler & 4100 \\
\hline
\end{tabular}

CORK fluid obtained 3 days after opening $\left(4.4-6.0 \times 10^{2}\right.$ cells $/ \mathrm{mL}$ of microbial cell density), the gamma-proteobacterial phylotypes, especially the Methylobactor phylotype, significantly decreased in the relative abundance and alpha-proteobacterial phylotypes also decreased in the relative clonal abundances (Fig. 6). In contrast, phylotypes of Deltaproteobacteria, Firmicutes (Alkaliphilius), Actinobacteria, Deinococcus-Thermus, and Archaea increased in relative abundances. Most archaeal phylotypes were related to extremophilic members such as hyperthermophiles and extreme halophiles that do not inhabit the cold and highly alkaline serpentine formation fluid regime of the SCS (Fig. 6). Although this simplified interpretation may lead to misunderstanding since the microbial cell density was decreased by fluid replacement during the 3-day discharge of the CORK fluid, phylotypes that increased in clonal abundances 3 days after the valve opening more likely represent truly indigenous microbial populations entrained by the serpentinite formation fluid derived from the deep. In the CORK fluid obtained by the Deep Sampler 45 months after the valve opening $\left(4.1-7.6 \times 10^{3}\right.$ cells $/ \mathrm{mL}$ of microbial cell density), the microbial phylotype composition changed drastically (Fig. 6). Most of the predominant phylotypes found in the fluids were different from those sampled 3 days after the valve was opened. At 45 months after, phylotypes of Deltaproteobacteria, Epsilonbacteria, Planktomycetes, Thermus-Deinococcus, and unclassified bacterial group dominated the library. It is still unclear why the CORK fluid obtained by the

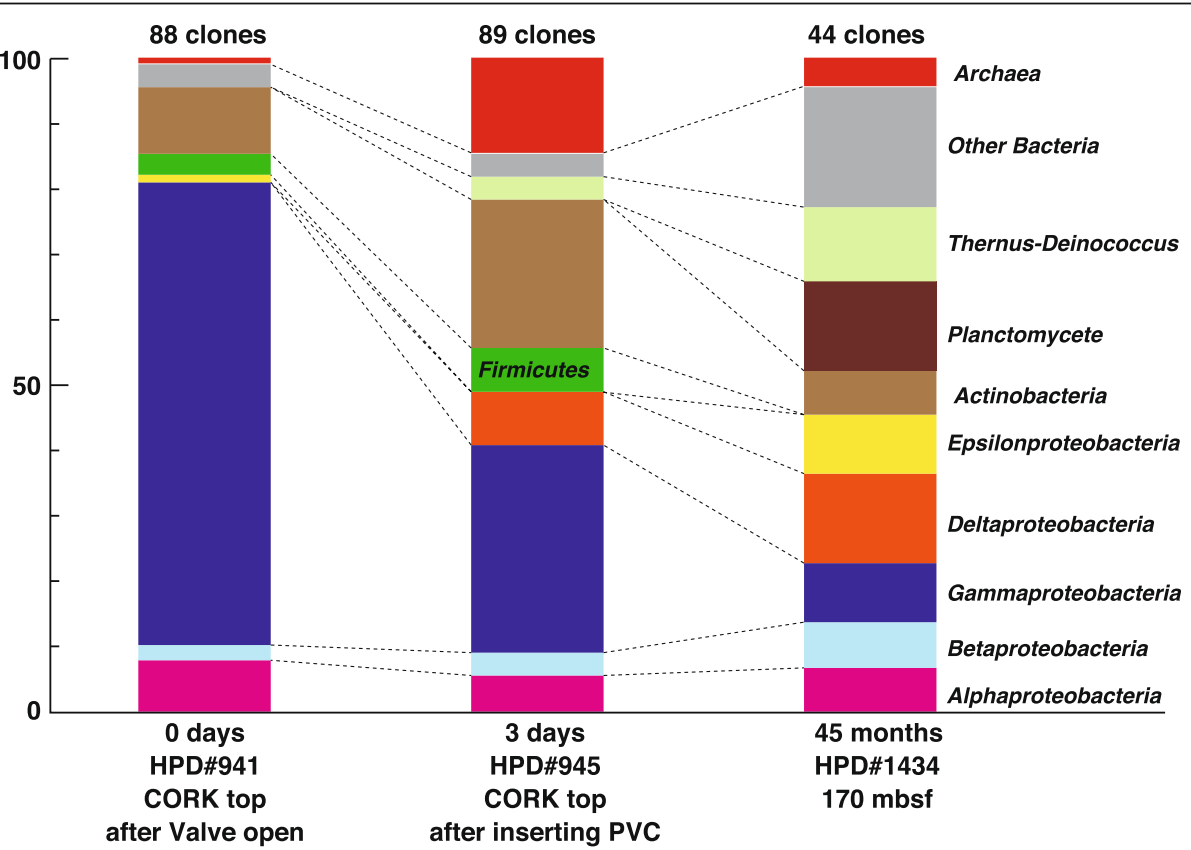

Fig. 6 Phylotype compositions of 16S rRNA genes in microbial communities of the CORK fluids. In total, 88, 89, and 44 clones were sequenced for the microbial communities in the CORK fluid samples at the time of valve opening $(0$ day), 3 days, and 45 months after the valve was opened, respectively 
Deep Sampler 45 months after had a higher cell density and a different microbial phylotype composition compared to the initial phase of CORK fluids. Nevertheless, it should be noted that the sampling scheme by the Deep Sampler was different from those by other fluid samplers, with the Deep Sampler ( $5 \mathrm{~cm}$ in diameter with the bottle being $1 \mathrm{~m}$ in length) was delivered to $170 \mathrm{mbsf}$ through the cased borehole. During the descent, the bottle could have hit the casing wall and detached accreted materials which likely contain microbial populations. Thus, the microbial community abundance and composition in the fluid obtained by the Deep Sampler may include, in addition to the microbial communities entrained from the formation fluid ("pelagic") flow, microbial populations specifically colonizing the steel casing pipe wall (Nakagawa et al. 2006; Nigro et al. 2012).

\section{Microbial carbon assimilation activity}

Microbial methane-, carbon monoxide-, formate-, acetate-, and leucine-assimilations (methanotrophic, carboxydotrophic, and heterotrophic activities) were examined with the CORK fluid samples obtained 1 to 6 days after the valve opening, and the bicarbonate-, methane-, formate-, and acetate-assimilation activities were examined with the CORK fluid samples obtained 5 months after the valve opening (Table 3). Methylomarinum vadi is a marine aerobic methanotroph optimally growing at $37{ }^{\circ} \mathrm{C}$ with a generation time of $2 \mathrm{~h}$ (Hirayama et al. 2013), and the methane assimilation rate of this methanotroph under the maintenance state for 1-day incubation was used as the positive control: $20 \mathrm{nmol} / \mathrm{day} / \mathrm{L}$ with a cell density of $1.3 \times 10^{4}$ cells $/ \mathrm{mL}$ (Table 3 ). In a similar manner, the autotrophic bicarbonate assimilation of natural deep-sea diffusing hydrothermal fluid was determined to be $2.3 \mathrm{nmol} /$ day/L with a cell density of $1.0 \times 10^{2}$ cells $/ \mathrm{mL}$ (Table 3 ).
These methane assimilation rates of $M$. vadi and the bicarbonate assimilation of the natural autotrophic microbial community in the discharging fluid are good comparative indexes to estimate the functions of the methanotrophic and autotrophic populations and even the whole microbial community in the CORK fluid.

The methane assimilation rates were determined to be 0.036, 0.049 and $0.039 \mathrm{nmol} /$ day/L in the CORK fluid under in situ, microaerobic and fully anaerobic conditions, respectively (Table 3 ). These values were significantly higher than those of the negative controls with the same tracers and are attributed to activity from the microbial populations in the CORK fluid. In addition, these values correspond to the methane assimilation activity by $2.3-3.2 \times 10^{1}$ cells $/ \mathrm{mL}$ through aerobic methanotrophy in the maintenance state. Carbon monoxide assimilation was not detected, while heterotrophic carbon assimilation was found to be the highest with formate $(0.06 \mathrm{nmol} / \mathrm{day} / \mathrm{L})$ and the lowest with acetate $(0.004 \mathrm{nmol} /$ day/L). These values are similar to or lower than the methane assimilation activity. In the CORK fluid obtained 5 months after the valve opening, autotrophic bicarbonate assimilation activity was the highest $(1.4 \mathrm{nmol} /$ day/L), and methanotrophic and heterotrophic (with formate and acetate) assimilations were lower at 0.2 and $0.05 \mathrm{nmol} / \mathrm{day} / \mathrm{L}$, respectively (Table 3). The methanotrophic assimilation was higher than any of the methane assimilation activities using the CORK fluid obtained 1 to 6 days after valve opening and the heterotrophic activity was similar to values reported previously from the CORK fluid, although the cell density in the CORK fluid decreased from $4.4-6.6 \times 10^{2}$ to $1.0 \times 10^{2}$ cells/mL during the 5 months period. Compared to the values of positive controls, these autotrophic and methanotrophic assimilation activities correspond to $7.0 \times 10^{1}$ cells $/ \mathrm{mL}$ of a natural autotrophic microbial

Table 3 Radio-isotope-tracer carbon assimilation of microbial community in the CORK fluids and positive controls

\begin{tabular}{|c|c|c|c|c|}
\hline Cruise ID & HPD dive\# & Tracer and incubation condition & $\begin{array}{l}\text { Incubation } \\
\text { time (days) }\end{array}$ & $\begin{array}{l}\text { Net assimilation } \\
\left(\mathrm{nmol} \text { day }^{-1} \mathrm{~L}^{-1}\right)\end{array}$ \\
\hline \multirow[t]{2}{*}{ NT09-01 } & 943 & ${ }^{14} \mathrm{C}_{-} \mathrm{CH}_{4}(0.25 \mathrm{MBq}$ per bottle and $0.4 \mathrm{mM})$ & 54 & 0.036 \\
\hline & 943 & ${ }^{14} \mathrm{C}_{-} \mathrm{CH}_{4}(0.25 \mathrm{MBq}$ per bottle and $0.4 \mathrm{mM})$ with $40 \mu \mathrm{M} \mathrm{O}_{2}$ & 54 & 0.049 \\
\hline \multirow[t]{3}{*}{ NT09-01 } & 947 & ${ }^{14} \mathrm{C}$-Leucine $(0.25 \mathrm{MBq}$ per bottle and $0.1 \mathrm{mM})$ & 52 & 0.014 \\
\hline & 947 & ${ }^{14} \mathrm{C}$-Formate (0.25 MBq per bottle and $\left.0.1 \mathrm{mM}\right)$ & 52 & 0.06 \\
\hline & 947 & ${ }^{14} \mathrm{C}$-Acetate $(0.25 \mathrm{MBq}$ per bottle and $0.1 \mathrm{mM})$ & 52 & 0.004 \\
\hline \multirow[t]{2}{*}{ NT09-01 } & 948 & ${ }^{14} \mathrm{C}_{-} \mathrm{CH}_{4}(0.25 \mathrm{MBq}$ per bottle and $0.4 \mathrm{mM})$ with $10 \mathrm{mM} \mathrm{NaSO}_{4}$ and $0.5 \mathrm{mM} \mathrm{Na}_{2} \mathrm{~S}$ & 49 & 0.039 \\
\hline & 948 & ${ }^{14} \mathrm{C}-\mathrm{CO}(0.25 \mathrm{MBq}$ per bottle and $0.4 \mathrm{mM})$ & 49 & n.d. ${ }^{a}$ \\
\hline \multirow[t]{3}{*}{ NT09-07 } & 1007 & ${ }^{14} \mathrm{C}_{-} \mathrm{CH}_{4}(0.25 \mathrm{MBq}$ per bottle and $0.4 \mathrm{mM})$ & 123 & 0.2 \\
\hline & 1007 & ${ }^{14} \mathrm{C}_{-} \mathrm{HCO}_{3}{ }^{-}(0.25 \mathrm{MBq}$ per bottle and $0.1 \mathrm{mM})$ with $0.4 \mathrm{mM} \mathrm{H} 2$ & 123 & 1.4 \\
\hline & 1009 & ${ }^{14} \mathrm{C}$-Formate and ${ }^{14} \mathrm{C}$-acetate (each of $0.25 \mathrm{MBq}$ per bottle and $0.1 \mathrm{mM}$ ) & 122 & 0.05 \\
\hline \multicolumn{2}{|c|}{ An aerobic methanotroph culture } & ${ }^{14} \mathrm{C}^{-} \mathrm{CH}_{4}(0.25 \mathrm{MBq}$ per bottle and $0.4 \mathrm{mM})$ & 1 & 20 \\
\hline \multicolumn{2}{|c|}{$\begin{array}{l}\text { An autotrophic community in } \\
\text { diffusing hydrothermal fluid }\end{array}$} & ${ }^{14} \mathrm{C}_{-} \mathrm{HCO}_{3}{ }^{-}$(0.25 MBq per bottle and $\left.0.1 \mathrm{mM}\right)$ & 5 & 2.3 \\
\hline
\end{tabular}


community and $1.3 \times 10^{2}$ cells $/ \mathrm{mL}$ of relatively inactive aerobic methanotrophs. These results indicate that the small number of microbial cells present in the CORK fluid obtained 5 months post-valve opening may be functionally active and capable of methanotrophic and autotrophic metabolisms. Nevertheless, radio-isotope-tracer experiments clearly indicate that microbial metabolisms and activities in the CORK fluids are detectable.

\section{Discussion}

\section{Post-drilling fluid alteration}

\section{Sulfate reduction coupled with $\mathrm{CH}_{4}$ oxidation}

Except for sulfate, the consistency in the major ion fluid chemistry between the CORK fluid and the DPW suggests that CORK fluids originate from the deep SCS formation fluid. Sulfate depletions in the CORK fluids, as opposed to the sulfate enrichment seen in the DPW, likely resulted from perturbation of the subseafloor geochemical environment during drilling activity. To estimate the abundance of reactive components (particularly $\mathrm{CH}_{4}$ and $\mathrm{H}_{2}$ ) in the pristine SCS formation fluid, it is necessary to consider processes associated with the drilling operation that could alter the fluid chemistry at $\sim 4{ }^{\circ} \mathrm{C}$.

A previous study (Wheat et al. 2008) pointed out that the methane oxidation can cause $\mathrm{SO}_{4}$ depletion in the CORK fluid, as follows:

$$
\mathrm{CH}_{4}+\mathrm{OH}^{-}+\mathrm{SO}_{4}{ }^{2-} \rightarrow \mathrm{CO}_{3}{ }^{2-}+\mathrm{HS}^{-}+2 \mathrm{H}_{2} \mathrm{O}(\mathrm{R} 1) \text {. }
$$

$\mathrm{R} 1$ produces $1 \mathrm{~mol}$ of dissolved sulfide and two equivalents of alkalinity for each mole of $\mathrm{OH}^{-}, \mathrm{CH}_{4}$, and $\mathrm{SO}_{4}{ }^{2}$ - consumed. This stoichiometry is consistent with the stoichiometry exhibited by the differences between the DPW and CORK fluids (Figs. 3 and 4). Assuming that R1 fully accounts for the $\sim 27 \mathrm{mM}$-equivalent sulfate consumption in the CORK fluids, the pristine SCS formation fluids would have contained $\mathrm{CH}_{4}$ at concentrations of 35-65 mM (Fig. 4c). The measured $\mathrm{pH}$ values of the CORK fluids (12.1-12.3) were higher than would be expected given the consumption of $\sim 27 \mathrm{mM} \mathrm{OH}^{-}$and a DPW with a $\mathrm{pH}=12.5 \pm 0.1$ that is representative of the SCS formation fluid (Fig. 4d). In addition, some of the measured total DIC contents of the CORK fluids (17$51 \mathrm{mM}$ ) were also inconsistent with a DIC concentration of $\sim 50 \mathrm{mM}$ expected by a combination of the $\sim 27 \mathrm{mM}$ DIC production and the $23 \mathrm{mM}$ DIC being originally present in the pristine SCS formation fluid (Mottl et al. 2003). Differences in the $\mathrm{OH}^{-}$and DIC values between the measured and predicted fluid compositions may be due to brucite-magnesite buffer through the following reaction:

$$
\mathrm{Mg}(\mathrm{OH})_{2}+\mathrm{CO}_{3}{ }^{2-} \Leftrightarrow \mathrm{MgCO}_{3}+2 \mathrm{OH}^{-}(\mathrm{R} 2) .
$$

The maximum $\mathrm{CH}_{4}$ concentration estimated $(65 \mathrm{mM})$ seems too high but is not unrealistic because it is comparable to the solubility of $\mathrm{CH}_{4}$ clathrate hydrate under relevant concentration-pressure-temperature-salinity condition within the SCS $\left(\sim 60 \mathrm{mM}\right.$ at $30 \mathrm{MPa}, 2{ }^{\circ} \mathrm{C}$ and $\left.3.5 \%\right)$ (Tishchenko et al. 2005). No geophysical data, however, support the presence of layered hydrate boundary, such as bottom simulating reflector (BSR).

\section{Possible $\mathrm{H}_{2}$ consumption coupled with sulfate reduction}

The low concentrations of $\mathrm{H}_{2}$ in the CORK fluid $(<0.1 \mathrm{mM})$ suggest that it may be consumed by sulfate reduction in addition to $\mathrm{CH}_{4} . \mathrm{H}_{2}$ oxidation coupled with sulfate reduction progresses as follows:

$$
4 \mathrm{H}_{2}+\mathrm{SO}_{4}{ }^{2-} \rightarrow \mathrm{HS}^{-}+\mathrm{OH}^{-}+3 \mathrm{H}_{2} \mathrm{O}(\mathrm{R} 3) .
$$

Because R3 produces $\mathrm{OH}^{-}, \mathrm{H}_{2}$ consumption during sulfate reduction may contribute to measured $\mathrm{pH}$ values that are higher than predicted by R1 (Fig. 4d). Assuming the $\mathrm{pH}$ balance is made by R1 and R3, the native SCS forma-

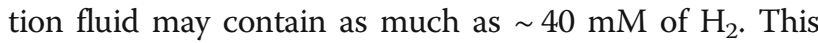
$\mathrm{H}_{2}$ level may be realistic because $27 \mathrm{mM}$ of $\mathrm{H}_{2}$ has been observed in a seafloor serpentinization-associated hydrothermal system at $>296{ }^{\circ} \mathrm{C}$ (Konn et al. 2015) and > $100 \mathrm{mM}$ of $\mathrm{H}_{2}$ can be attained through serpentinization at $200-300{ }^{\circ} \mathrm{C}$ from thermodynamic calculation (McCollom and Bach 2009). If the cool SCS formation fluid contains such abundant $\mathrm{H}_{2}$, the reduction of $\mathrm{CO}_{2}$ to form $\mathrm{CH}_{4}$ is thermodynamically favorable, according to the following reaction:

$$
4 \mathrm{H}_{2}+\mathrm{CO}_{3}{ }^{2-} \rightarrow \mathrm{CH}_{4}+\mathrm{H}_{2} \mathrm{O}+2 \mathrm{OH}^{-}(\mathrm{R} 4) .
$$

However, abiotic $\mathrm{CH}_{4}$ formation represented by $\mathrm{R} 4$ is unlikely due to kinetic barriers at the low temperatures within the SCS body $\left(4^{\circ} \mathrm{C}\right)$. In addition to $\mathrm{CH}_{4}$ and $\mathrm{H}_{2}$, native iron and other metals in the casing pipe may function as reductant and cation for the dissolved sulfate removal.

\section{Drilling induced sulfate reduction}

The discussions above suggest that abundant $\mathrm{CH}_{4}$ and $\mathrm{SO}_{4}$ coexist in the native SCS formation fluid and is consistent with their presence in the DPW (Mottl et al. 2003). This coexistence is unusual in the subseafloor environment because sulfate reduction coupled with methane oxidation is thermodynamically favorable and usually promoted by ubiquitous microbial consortia of methanotrophic archaea and sulfate reducing bacteria, known as AOM (Orphan et al. 2001). In other words, both abundant $\mathrm{CH}_{4}$ and $\mathrm{SO}_{4}$ in the native SCS formation fluid point to unusually slow kinetics of the sulfate reduction (R1) within the native SCS body. In fact, $\mathrm{SO}_{4}$ reduction coupled with $\mathrm{CH}_{4}$ oxidation (R1) likely occurs in the post-drilling CORK fluids, derived from 
subseafloor regions affected by the Hole 1200C drilling, casing, and/or CORK installation.

Drilling-induced introduction of external microbial communities into the subsurface environment may account for the post-drilling progression of $\mathrm{R} 1$ due to AOM. While the relatively impermeable serpentinite matrix prevented access of the over-pressured aquifer to the microbe-bearing seawater, the drilling operation and the hole made the deep aquifer exposed to deep-sea water and shallow subseafloor sediment containing exogenous microbial communities, including AOM consortia (Mottl et al. 2003). However, the post-drilling microbial AOM function is likely insignificant, as suggested by multiple lines of microbiological evidence such as small biomass, a lack of evidence for 16S rRNA gene phylotype signatures of previously known AOM consortia, and the negligible $\mathrm{CH}_{4}$ assimilation during the ${ }^{14} \mathrm{C}$ experiment (see the "Results" section). Assuming that the dissimilatory AOM activity of consortia does not exceed $10^{2}$ times higher than the anoxic methane assimilation rate, as the highest methane assimilation activity estimated in this study is $0.0002 \mu \mathrm{mol} / \mathrm{day} / \mathrm{L}$, it can be calculated that a $27 \mathrm{mmol} / \mathrm{L} \mathrm{SO}_{4}$ consumption requires $>10^{6}$ days. This amount of time is much longer than the time elapsed since drilling ceased $\left(<10^{4}\right.$ days). This calculation, together with other microbiological results, suggests that the microbial AOM function is not significantly involved in the post-drilling $\mathrm{CH}_{4}-\mathrm{SO}_{4}$ reactions, based on experimental conditions at $2{ }^{\circ} \mathrm{C}$. Although faster microbial reaction rates may occur deeper within the seamount where the environment is warmer, the extent of their involvement would be still negligible. It is noted that microbial activity at the pristine interior of the SCS body is more stricly limited than the rate calculated above due to their impermeability and over-pressured aquifer, and probably less biomass.

There are no reliable data for the kinetics of R1 without the involvement of microbial AOM. However, the sudden and rapid progression of R1 after drilling would require some catalytic effects associated with the drilling, casing, and CORK installation operations, other than the introduction of AOM populations. A possible catalyst introduced by drilling and casing the borehole is native iron and other metals used in the casing pipe and the CORK structure. Transition metals such as iron and nickel generally exhibit catalytic function for redox reactions due to their multiple valences. In addition to catalytic reactions occurring locally on the metal surface, high electron conductivity of the elongate casing pipe allows remotely located reducing and oxidizing molecules to be reacted through electron transfer, similar to how a battery functions. Nevertheless, the extent to which drilling and casing operations promoted abiotic sulfate reduction coupled with $\mathrm{CH}_{4}$ oxidation is still not entirely clear.
Origins of $\mathrm{CH}_{4}$ and $\mathrm{SO}_{4}$ in the native serpentine formation fluid of the SCS

Abiotic hydrocarbon synthesis associated with serpentinization-environmental factors

Although it is difficult in natural environments of the modern Earth to distinguish between abiotic synthesis of $\mathrm{CH}_{4}$ from other $\mathrm{CH}_{4}$ sources such as microbial methanogenesis (biogenic $\mathrm{CH}_{4}$ ) and thermal degradation of sedimentary organic matter (thermogenic $\mathrm{CH}_{4}$ ) (see reviews, Etiope and Sherwood Lollar, 2013 for example), multiple lines of geochemical and microbiological evidence suggest that contributions of biogenic and thermogenic $\mathrm{CH}_{4}$ in the SCS system are not signficant. During the early stage of subduction, where the temperatures are below the known $122{ }^{\circ} \mathrm{C}$ upper limit for the growth of microbes (Takai et al. 2008), microbial methanogenesis is probably absent or insignificant due to the abundantly dissolved sulfate in the sediment pore water in the Pacific plate eastward from the Mariana Trench (ODP sites 800-802) (France-Lanord et al. 1992). During the later stages of subduction, temperatures exceed $122{ }^{\circ} \mathrm{C}$, which is too high for microbial life to survive. The same is also true for regions of extensive serpentinization within the overlying mantle wedge. In the SCS formation fluid regime, where temperatures again become cool and habitable, there is little potential to produce abundant $\mathrm{CH}_{4}$ due to low biomass and microbial function, revealed by the 45 months long observation of the CORK fluids. In addition, the highest known $\mathrm{pH}$ limit for the growth of methanogens is $<10$ (Methanosalsum zhilinae: Mathrani et al. 1988), significantly lower than the $\mathrm{pH}$ of $>12$ in the SCS fluids. The extremely low organic contents in the SCS serpentine mud (Mottl et al. 2003) indicate that there is little potential for thermogenic hydrocarbon generation beneath the SCS.

Possibility of abiotic synthesis from thermodynamic and kinetic viewpoints Abiotic organic synthesis, including the generation of $\mathrm{CH}_{4}$ from $\mathrm{CO}_{2}$, is generally more favorable at lower temperatures from a thermodynamic viewpoint despite unfavorable kinetic constraints (e.g., McCollom, 2008). In the case of the SCS, thermodynamically favorable conditions for the abiotic synthesis of $\mathrm{CH}_{4}$ is expected through the entire formation fluid regime due to sufficiently reducing conditions resulting from serpentinization occur at $200-300{ }^{\circ} \mathrm{C}$ (McCollom and Bach, 2009) and subsequent cooled as fluids ascend. The ascending fluid is quenched sufficiently for microbial activity $\left(122{ }^{\circ} \mathrm{C}\right.$ : Takai et al. 2008) at $13 \mathrm{~km}$ below the seafloor, estimated from the thermal gradient observed $\left(9.4{ }^{\circ} \mathrm{C} / \mathrm{km}\right)$. Since formation fluids probably ascend on a geological time span, continuous abiotic synthesis and accumulation of organic compounds is plausible, even at extremely low reaction rates. 
The rate of abiotic hydrocarbon synthesis depends on the carbon substrate (McCollom et al. 2010). McCollom et al. (2010) demonstrated that CO-based synthesis is feasible within an experimental timeframe. Even when the CO-based abiotic synthesis is feasible under conditions of the SCS formation fluid, $\mathrm{CO}$ production from $\mathrm{CO}_{2}$ represents a bottle-neck in the process due to the several orders of magnitude less $\mathrm{CO}$ compared to $\mathrm{CO}_{2}$ in the CORK fluid. Abiotic methanogenesis based on solid-phase carbon, such as graphite derived from metamorphism and carbonate mineral deposits (Etiope and Sherwood Lollar, 2013), cannot be precluded, although the possibility cannot be evaluated here due to limited information about the rates of such processes.

Suggestions from stable isotope signatures Stable isotope signatures should be interpreted in the context of isotope ratios of individual molecules (Fig. 5a, b) and isotope fractionation between relevant molecules (Fig. 5c) (Etiope and Sherwood Lollar, 2013). The $\mathrm{CH}_{4}-\mathrm{H}_{2} \mathrm{O}$ hydrogen isotopic fractionation factor of the CORK fluid $\left(\alpha^{\mathrm{H}}{ }_{\mathrm{CH} 4-\mathrm{H} 2 \mathrm{O}}\right)$ is 0.87 , which is inconsistent with typical biogenic values of $\sim 0.70$ (Okumura et al. 2016b) (Fig. 5c). Thermogenic $\mathrm{CH}_{4}$ reservoirs generally have $\alpha^{\mathrm{H}}{ }_{\mathrm{CH} 4-\mathrm{H} 2 \mathrm{O}}$ values corresponding to the $\mathrm{CH}_{4}-\mathrm{H}_{2} \mathrm{O}$ isotope equilibrium values at the formation/reservoir temperature (e.g., Stolper et al. 2014; Wang et al. 2015). The $\alpha^{\mathrm{H}}{ }_{\mathrm{CH} 4-\mathrm{H} 2 \mathrm{O}}$ and $\alpha^{\mathrm{H}}{ }_{\mathrm{C} 2 \mathrm{H} 6-\mathrm{H} 2 \mathrm{O}}$ values of the CORK fluids ( $>0.86$ ) correspond to those of the isotope equilibrium values at $>200{ }^{\circ} \mathrm{C}$ (Fig. 5b, c) (Horibe and Craig 1995; Reeves et al. 2012), consistent with the uppermost temperature expected at the plate boundary and mantle wedge beneath the SCS $\left(\sim 350{ }^{\circ} \mathrm{C}\right.$ ) (Mottl et al. 2004; Hulme et al. 2010). This suggests that the hydrogen isotope signature of hydrocarbons recorded at $>200{ }^{\circ} \mathrm{C}$ has not been altered after these fluids have been cooled to their discharge temperatures. The lack of hydrogen isotope re-equilibrium between $\mathrm{CH}_{4}$ and $\mathrm{H}_{2} \mathrm{O}$ seems consistent with the half-life for equilibrium exchange, estimated to be approximately one million years at $200{ }^{\circ} \mathrm{C}$ (Sessions et al. 2004; Wang et al. 2015). In addition, the hydrogen isotope signature shows no evidence for a contribution of biogenic $\mathrm{CH}_{4}$ produced in the cool formation fluid regime of the SCS. The $\mathrm{H}_{2}-\mathrm{H}_{2} \mathrm{O}$ thermometer value, indicating $2{ }^{\circ} \mathrm{C}$, is inconsistent with the $\mathrm{CH}_{4}-\mathrm{H}_{2} \mathrm{O}$ thermometer but reasonable because of the more feasible $\mathrm{H}_{2}-\mathrm{H}_{2} \mathrm{O}$ equilibrium, even at lower temperatures (Valentine et al. 2004; Proskurowski et al. 2008; Kawagucci et al. 2010; 2016; Pester et al. 2018).

The $\delta^{13} \mathrm{C}-\mathrm{CH}_{4}$ values of about $-37 \%$ and the isotope fractionation between $\mathrm{CH}_{4}$-DIC $\left(\alpha_{\mathrm{CH} 4-\mathrm{DIC}}\right)$ of $\sim 0.963$ seem to be an equivocal signature for thermogenic, biogenic, or abiotic origins (Fig. 5c) (Kawagucci et al. 2013 and references therein). Hydrothermal experiments simulating hydrothermal hydrocarbons generation from the seafloor sediment at $325-400{ }^{\circ} \mathrm{C}$ show an $\alpha^{\mathrm{C}}{ }_{\mathrm{CH} 4-\mathrm{CO} 2}$ as high as 0.985 (Seewald et al. 1994) (Fig. 5c). Carbon isotope fractionation produced by microbial hydrogenotrophic methanogenesis in the seafloor sediment typically displays $\alpha^{\mathrm{C}}{ }_{\mathrm{CH} 4-\mathrm{DIC}}$ of $\sim 0.930$ (Okumura et al. 2016b and references therein). It is also known, however, that microbial metabolisms sometimes cause unusual isotope effects under extreme growth and survival conditions (e.g., Valentine et al. 2004; Penning et al. 2005; Takai et al. 2008). Microbial methanogenesis in the SCS formation fluid regime may cause an unusual carbon isotope effect as $\mathrm{CO}_{3}{ }^{2-}$ is the dominant DIC speciation in highly alkaline solutions.

Carbon and hydrogen isotope systematics of CORK fluids suggest that abiotic methanogenesis is occurring at $>\sim 200{ }^{\circ} \mathrm{C}$. Hydrothermal experiments, demonstrating $\mathrm{CO}$ - and $\mathrm{CO}_{2}$-based abiotic hydrocarbon syntheses, provide consistent $\alpha^{\mathrm{C}}{ }_{\mathrm{CH} 4-\mathrm{CO} 2}$ values of $0.97-0.98$ (Fu et al. 2007; McCollom et al. 2010), slightly higher than that observed in the CORK fluids (0.963). Experimental determination of $\mathrm{CH}_{4}-\mathrm{CO}_{2}$ isotope equilibrium at $200{ }^{\circ} \mathrm{C}$ exhibits a $\alpha^{\mathrm{C}}{ }_{\mathrm{CH} 4-\mathrm{CO} 2}$ of 0.966 (Horita, 2001), very close to the value observed from the CORK fluid (Fig. $5 \mathrm{c}$ ). Although carbon isotope exchange between $\mathrm{CH}_{4}-\mathrm{CO}_{2}$ below $\sim 400{ }^{\circ} \mathrm{C}$ is generally thought to become kinetically sluggish without a catalyst, particularly in the $\mathrm{CH}_{4}$-generating direction (e.g., McCollom, 2008), the $\mathrm{CH}_{4}-\mathrm{CO}_{2}$ isotope equilibrium could be attained at $\sim 200{ }^{\circ} \mathrm{C}$ beneath the SCS because of thermodynamically favorable condition for $\mathrm{CH}_{4}$ generation and geological time span. For the hydrogen isotope equilibrium between hydrocarbons and $\mathrm{H}_{2} \mathrm{O}$, terminal locality of hydrogen atoms would be more feasible for the exchange with the surrounding hydrogen-bearing molecules, namely, $\mathrm{H}_{2} \mathrm{O}$ (Reeves et al. 2012; Wang et al. 2015). The $H$ exchange would erase the extremely D-depleted signature $\left(\alpha_{\mathrm{CH} 4-\mathrm{H} 2 \mathrm{O}}^{\mathrm{H}}=\sim 0.45\right.$ : McCollom et al. 2010) exhibited by the (experimental) abiotic $\mathrm{CH}_{4}$ generation. Carbon and hydrogen isotopic thermometers both indicating $>\sim 200{ }^{\circ} \mathrm{C}$ left in the $2{ }^{\circ} \mathrm{C}$ CORK fluid (Fig. 5c), imply that the reactions for isotope exchange are limited at lower temperatures. Thus, the rate of abiotic synthesis would decease after cooling the SCS formation fluid below $200{ }^{\circ} \mathrm{C}$, yet it must continue within the serpentinite matrix at lower temperatures.

\section{Slab-derived $\mathrm{SO}_{4}$ conservation through serpentinization}

The abundant dissolved sulfate in the SCS formation fluid was thought to originate from sulfate in the subducting slab (Mottl et al. 2003). This conclusion seems inconsistent with abiotic organic synthesis via serpentinization, in which sulfate should be reduced from a thermodynamic viewpoint. On the other hand, closed-system experiments 
simulating serpentinization at $200-300{ }^{\circ} \mathrm{C}$ (Janecky and Seyfried Jr., 1986; Seyfried 2007) confirmed barriers to sulfate reduction during serpentinization due to rapid sulfate precipitation as anhydrite upon initial heating of the experiment and its subsequent metastable persistence, even in a highly reducing fluid. Accordingly, anhydrite precipitation in the downgoing slab may facilitate sulfate conservation through high-temperature regions of subduction and diapir. In addition, a recent quadruple sulfur isotope study of SCS DPW and CORK fluid suggests that the mantle wedge represents one of the possible sources of sulfate in the SCS formation fluid (Aoyama et al. 2018).

\section{Hypothetical sequence of geochemical processes in the SCS system}

We propose a hypothesis for the possible sequence of (bio) geochemical processes in the SCS serpentinite formation fluid regime, based on CORK fluid characteristics and observations from previous studies (Fig. 7). The oligotrophic western North Pacific water provides little sedimentary organic matter, resulting in pelagic sediments of the Pacific plate eastward from the Mariana
Trench (ODP sites 800-802) that contain sulfate-rich porewater (France-Lanord et al. 1992; Alt and Shanks III, 2006) and low sedimentary biomass (Kellmeyer et al., 2012). Global seafloor drilling that penetrates into the upper basaltic crust (e.g., Gieskes et al. 1990, 1993; Hensen and Wallmann, 2005) have indeed revealed dissolved sulfate that is ubiquitously abundant in the uppermost part of subducting plate, despite their great depth and distance from the trench seafloor. At an early stage of subduction, some or all of the porewater sulfate is precipitated as anhydrite with requisite Ca supplied by dissolution of sedimentary calcite or reactions with involving basaltic crust. At the deep plate boundary region at $\sim 0.6 \mathrm{GPa}$ and $\leq$ $\sim 350{ }^{\circ} \mathrm{C}$ (Hulme et al. 2010), metamorphic processes such as compactive dewatering, expulsion of interlayer water, dehydration, and decarbonation forms the DIC-rich initial upwelling fluid (Mottl et al. 2004), which harbors no microbial population due to its high temperature. The initial fluid accompanied with metamorphic minerals such as blueschist and anhydrite penetrates into the overlying mantle wedge and induces serpentinization. Extensive serpentinization produces highly alkaline and strongly reducing $\mathrm{H}_{2}$-rich fluid

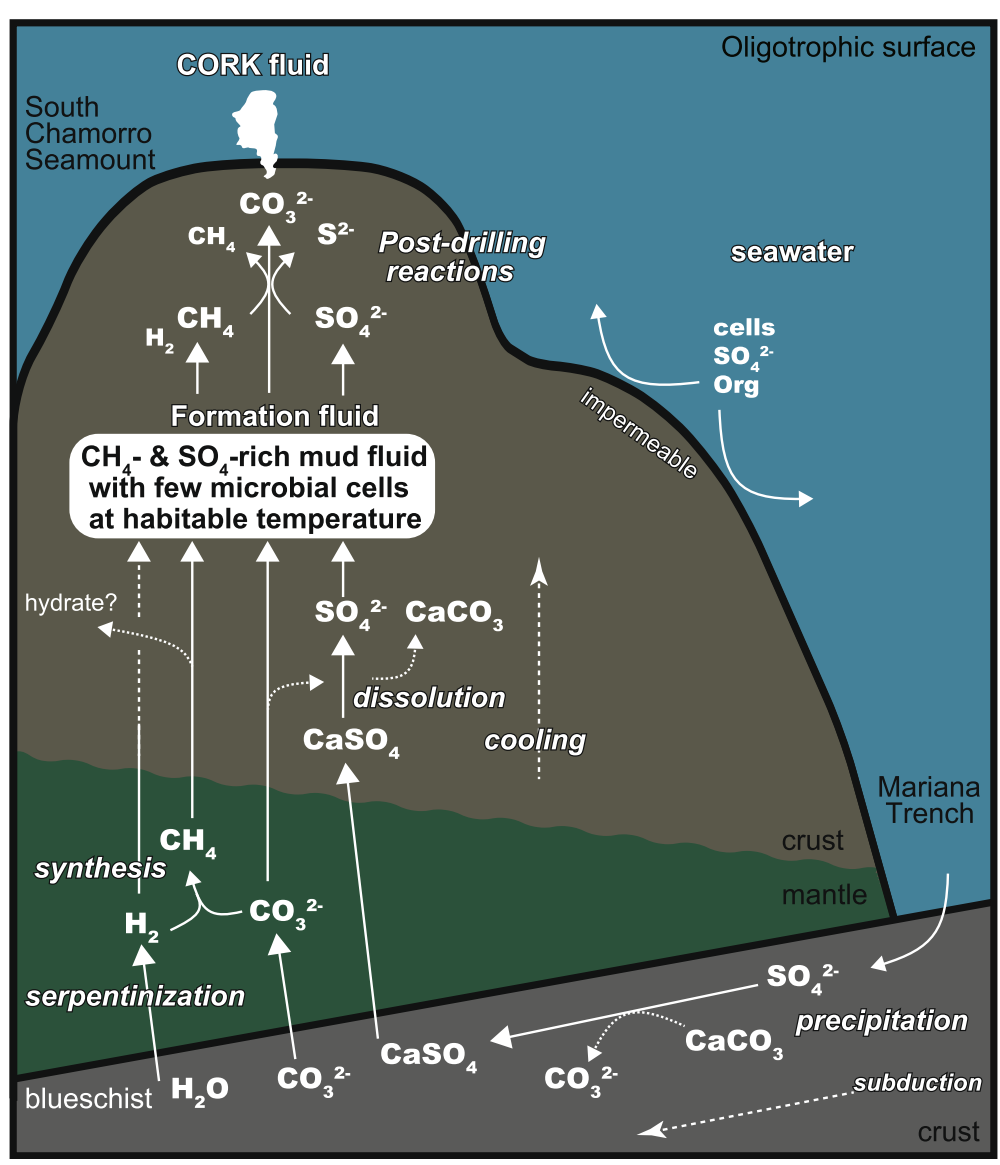

Fig. 7 Illustration for possible C-S-H reactions beneath the SCS. "Cells" represents microbial cells and "Org" represents organic matter in the seawater 
(McCollom and Bach 2009), leading to the thermodynamic conditions favorable for the abiotic organic synthesis from slab-derived inorganic carbon. Sulfate minerals are not reduced, due to kinetic constraints. The abiotic synthesis of organic molecules occurs within the ascending serpentinite mud until its temperature decreases to $\sim 200{ }^{\circ} \mathrm{C}$. Further ascend and cooling decrease the rate of abiotic synthesis while allowing for the dissolution of anhydrite (anhydrite-derived calcium is completely removed by abundant DIC). This sequence results in the co-existence of abiotic $\mathrm{CH}_{4}$ (and possibly $\mathrm{H}_{2}, \mathrm{C}_{2+}$ hydrocarbons, and some organic matter) and slab-derived dissolved $\mathrm{SO}_{4}$ in the SCS formation fluid. Although the abundant $\mathrm{CH}_{4}$ and $\mathrm{SO}_{4}$ exhibit sufficient bioavailable energy potentials (Nakamura and Takai 2014) within the habitable temperature range $\left(<\sim 122{ }^{\circ} \mathrm{C}\right.$ : Takai et al. 2008), limited microbial biomass and activity are present because the relatively impermeable SCS prevents penetration of microbial community from ambient seawater. As the major conduit for the mud/fluid ascending path consists of $60-100 \%$ serpentinite muds (Shipboard Sci. Party 2002), the fluid-serpentinite interaction rather than fluid-peridotite interaction (serpentinization) dominates the current fluid chemistry of the SCS formation fluid. The highly alkaline porewater $\mathrm{pH}$ of $\sim 12.5$ likely prevents the development of subseafloor microbial community due to the $\mathrm{CO}_{3}{ }^{2-}$-dominated DIC speciation being disadvantageous for autotrophy (e.g., Schrenk et al. 2013) whereas the known upper $\mathrm{pH}$ limit for chemoorganotrophic microorganisms is 12.4 (Takai et al. 2001). Ongoing reactions between the $\mathrm{CH}_{4}$ and $\mathrm{SO}_{4}$, as observed in this study, would have been triggered by the very recent ODP drilling and casing operations carried out in 2001 (Shipboard Sci. Party 2002; Wheat et al. 2008).

\section{Conclusions}

The present study investigated the chemical and microbiological characteristics of formation fluids from a serpentinite mud volcano, the SCS. The gas chemistry characterized by abundant $\mathrm{CH}_{4}$ and low $\mathrm{H}_{2}$ is the first of its kind from deep-sea highly alkaline (serpentinization-associated) geofluid systems. The SCS formation fluid regime may also represent the first reported example on Earth where abiotic processes are conspicuous with little biotic processes, despite conditions with sufficient bioavailable energy potentials and temperatures within the habitable range. However, there are still many uncertainties associated with the hypothesis presented here. It is not sufficient to clearly distinguish the geochemical processes in each of the spatio-temporally different stages of fluid-rock interactions beneath the SCS, such as metamorphism associated with subduction, fluid released from the plate boundary zone, extensive serpentinization at the wedge mantle, fluid maturation and cooling in the ascending pathway, episodic mud volcanism, and mass wasting of the SCS body. The behavior of sulfate in subduction systems is a key factor for understanding the (bio) geochemical cycle at forearc geofluid systems. Constraint in keeping the co-existence of the (probably) slab-derived sulfate and abiotic $\mathrm{CH}_{4}$ in the SCS formation, unexpected due to the strong thermodynamic drive for their reaction, remains unidentified. Broadly speaking, abiotic organic synthesis associated with subseafloor serpentinization has been considered to progress in many of the natural serpentinization-associated geofluid systems including the SCS, but has never been confirmed by multiple lines of solid evidences that serve to distinguish it from organic matter degradation and biological carbon fixation. Future studies of the SCS and other serpentinite mud volcanoes in the Mariana forearc are needed to refine conceptual models of reactions within these interesting features that link seafloor materials with the descending slab.

\section{Additional file}

Additional file 1: Table S1. Results of chemical analyses of the CORK fluid (XLSX $49 \mathrm{~kb}$ )

\section{Abbreviations \\ CORK: Circulation Obviation Retrofit Kit; DPW: Deep porewater; IC: Ion chromatography; ICP-AES: Inductively coupled plasma atomic emission spectrometry; ICP-MS: Inductively coupled plasma mass spectrometry; ODP: Ocean Drilling Program; PVC: Polyvinyl chloride; ROV: Remotely operated vehicle; SCS: South Chamorro Seamount}

\section{Acknowledgements}

We thank the operation team of the ROV Hyper-Dolphin and the crews of RN Natsushima for their skillful support during cruises NT09-1, NT09-7, NT12-04, and NT12-23. We also thank Dr. Uta Konno for gas and isotope analyses. Drs. Kentaro Nakamura, Takazo Shibuya, and Chong Chen are gratefully acknowledged for useful and fruitful discussions. SK thanks Prof. Gretchen Bernasconi-Green for providing space and opportunity to draft the manuscript as an academic visitor of ETH Zürich.

\section{Funding}

This work was partly supported by JSPS KAKENHI Grant Number 25701004 (SK).

Availability of data and materials

All analytical results of this study are included in the main text and tables.

\section{Authors' contributions}

SK, JM, CGW, and KT proposed the topic, conceived, and designed the study. All authors joined cruises for sample collection. JM, YM, JSS, and CGW analyzed the samples and helped in their interpretation. JSS and CGW collaborated with the corresponding author (SK) in the construction of manuscript. All authors read and approved the final manuscript.

Competing interests

The authors declare that they have no competing interest.

\section{Publisher's Note}

Springer Nature remains neutral with regard to jurisdictional claims in published maps and institutional affiliations.

\section{Author details}

${ }^{1}$ Department of Subsurface Geobiological Analysis and Research (D-SUGAR), Japan Agency for Marine-Earth Science and Technology (JAMSTEC), 2-15 Natsushima-cho, Yokosuka 237-0061, Japan. ${ }^{2}$ Kochi Institute for Core Sample Research, Japan Agency for Marine-Earth Science and Technology (JAMSTEC), Nankoku, Kochi 783-8502, Japan. ${ }^{3}$ Department Marine Chemistry and 
Geochemistry (MC\&G), Woods Hole Oceanographic Institution (WHOI), Woods Hole, MA 02543, USA. ${ }^{4}$ Global Undersea Research Unit, University of Alaska Fairbanks, P. O. Box 475, Moss Landing, CA 95039, USA. ${ }^{5}$ Institute of Geochemistry and Petrology, ETH Zürich, Zürich, Switzerland.

\section{Received: 9 May 2018 Accepted: 19 October 2018}

Published online: 14 November 2018

\section{References}

Alt JC, Shanks WC III (2006) Stable isotope compositions of serpentinite seamounts in the Mariana forearc: serpentinization processes, fluid sources and sulfur metasomatism. Earth Planet Sci Lett 242:272-285.

Aoyama S, Nishizawa M, Miyazaki J, Shibuya T, Ueno Y, Takai K (2018) Recycled Archean sulfur in the mantle wedge of the Mariana Forearc and microbial sulfate reduction within an extremely alkaline serpentine seamount. Earth Planet Sci Lett 491:109-120.

Barnes I, LaMarche j VC, Himmelberg G (1967) Geochemical evidence of presentday serpentinization. Science 156:830-832.

Barnes I, O'neil JR, Trescases JJ (1978) Present day serpentinization in New Caledonia, Oman and Yugoslavia. Geochim Cosmochim Acta 42:144-145.

Burruss RC, Laughrey CD (2010) Carbon and hydrogen isotopic reversals in deep basin gas: Evidence for limits to the stability of hydrocarbons. Organic Geochemistry 41:1285-1296. https://doi.org/10.1016/j.orggeochem.2010.09. 008.

Charlou JL, Donval JP, Fouquet Y, Jean-Baptiste P, Holm N (2002) Geochemistry of high $\mathrm{H} 2$ and $\mathrm{CH} 4$ vent fluids issuing from ultramafic rocks at the Rainbow hydrothermal field (36¹ $14^{\prime} \mathrm{N}$, MAR). Chem Geol 191:345-359.

de Lange GJ, Cranston RE, Hydes DH, Boust D (1992) Extraction of pore water from marine sediments: a review of possible artifacts with pertinent examples from the North Atlantic. Mar Geol 109:53-76.

Etiope G, Sherwood Lollar B (2013) Abiotic methane on earth. Rev Geophys 51:1-24.

France-Lanord C, Michard A, Karpoff AM (1992) Major element and Sr isotope composition of interstitial waters in sediments from leg 129: the role of diagenetic reactions. In: Larson RL, Lancelot $Y$ et al (eds) Proceedings of teh Ocean Drilling Program Scientific Results, vol 129, pp 267-281.

Früh-Green GL, Kelley DS, Bernasconi SM, Karson JA, Ludwig KA, Butterfield DA, Boschi C, Proskurowski G (2003) 30,000 years of hydrothermal activity at the Lost City vent field. Science 301:495-498.

Fryer $\mathrm{P}$ (2011) Serpentinite mud volcanism: observations, processes, and implications. Annu Rev Mar Sci 4:345-373.

Fryer P, Mottl MJ (1997) "Shinkai 6500" investigations of a resurgent mud volcano on the Southeastern Mariana forearc. JAMSTEC-R 13:103-114.

Fu Q, Sherwood Lollar B, Horita J, Lacrampe-Couloume G, Seyfried WE Jr (2007) Abiotic formation of hydrocarbons under hydrothermal conditions: constraints from chemical and isotope data. Geochim Cosmochim Acta 71: 1982-1998.

Gieskes J, Gamo T, Kastner M (1993) Major and minor element geochemistry of interstitial waters of site 808 , Nankai trough: an overview. In: Hill IA, Taira A, Firth JV et al (eds) Scientific results, Ocean Drilling Program, Leg 131. Ocean Drilling Program, College Station, Texas, pp 387-396.

Gieskes JM, Vroluk P, Blank G (1990) Hydrogeochemistry of the Northern Barbados accretionary complex transect: Ocean Drilling Project Leg 110. Geophys Res 95:8809-8818.

Hensen C, Wallmann K (2005) Methane formation at Costa Rica continental margin - constraints for gas hydrate inventories and cross-décollment fluid flow. Earth Planet Sci Lett 236:41-60.

Hirayama H, Fuse H, Abe M, Miyazaki M, Nakamura T, Nunoura T, Furushima Y, Yamamoto H, Takai K (2013) Methylomarinum vadi gen. nov. sp. Nov., a methanotroph isolated from two distinct marine environments. Int J Syst Evol Microbiol 63:1073-1082.

Hirayama H, Sunamura M, Takai K, Nunoura T, Noguchi T, Oida H, Furushima Y, Yamamoto H, Oomori T, Horikoshi K (2007) Culture-dependent and -independent characterization of microbial communities associated with a shallow submarine hydrothermal system occurring within a coral reef off Taketomi Island, Japan. Appl Environ Microbiol 73:7642-7656.

Homma A, Tsukahara H (2008) Chemical characteristics of hot spring water and geological environment in the northernmost area of the Itoigawa Shizuoka tectonic line. Bull Earthw Res Inst Univ Tokyo 83:217-225.

Horibe Y, Craig H (1995) D/H fractionation in the system methane-hydrogenwater. Geochim Cosmochim Acta 59:5209-5217.
Horita J (2001) Carbon isotope exchange in the system CO2-CH4 at elevated temperatures. Geochim Cosmochim Acta 65:1907-1919.

Hulme SM, Wheat CG, Fryer P, Mottl MJ (2010) Pore water chemistry of the Mariana serpentinite mud volcanoes: a window to the seismogenic zone. Geochem Geophys Geosyst 11:Q01X09. https://doi.org/10.1029/ 2009GC002674.

Janecky DR, Seyfried WE Jr (1986) Hydrothermal serpentinization of peridotite within the oceanic crust: experimental investigations of mineralogy and major element chemistry. Geochim Cosmochim Acta 50:1357-1378.

Kawagucci S, Miyazaki J, Noguchi T, Okamura K, Shibuya T, Watsuji T et al (2016) Fluid chemistry in the solitaire and dodo hydrothermal fields of the central Indian ridge. Geofluids 5:988-1005. https://doi.org/10.1111/gfl.12201.

Kawagucci S, Toki T, Ishibashi J, Takai K, Ito M, Oomori T, Gamo T (2010) Isotopic variation of molecular hydrogen in $20^{\circ}-375^{\circ} \mathrm{C}$ hydrothermal fluids as detected by a new analytical method. J Geophys Res 115:G03021-9. https:// doi.org/10.1029/2009JG001203.

Kawagucci S, Ueno Y, Takai K, Toki T, Ito M, Inoue K, Makabe A, Yoshida N, Muramatsu Y, Takahata N, Sano Y, Narita T, Teranishi G, Obata H, Nakagawa S, Nunoura T, Gamo T (2013) Geochemical origin of hydrothermal fluid methane in sediment-associated fields and its relevance to the geographical distribution of whole hydrothermal circulation. Chem Geol 339:213-225.

Kelley DS, Karson JA, Blackman DK, Früh-Green GL, Butterfield DA et al (2001) An off-oxis hydrothermal vent field near the Mid-Atlantic Ridge at $30^{\circ} \mathrm{N}$. Nature 412:145-149.

Kellmeyer J, Pockalny R, Adhikari RR, Smith DC, D'Hondt S (2012) Global distribution of microbial abundance and biomass in subseafloor sediment. PNAS 109:16213-16216.

Konn C, Charlou JL, Lolm NG, Mousis O (2015) The production of methane, hydrogen, and organic compound in ultramafic-hosted hydrothermal vents of the Mid-Atlantic Ridge. Astrobiology 15:381-399.

Kumagai H, Nakamura N, Toki T, Morishita T, Okino K, Ishibashi J et al (2008) Geological background of the Kairei and Edmond hydrothermal fields along the Central Indian ridge: implications of their vent fluids' distinct chemistry. Geofluids 8:239-251.

Mathrani IM, Boone DR, Mah RA, Fox GE, Lau PP (1988) Methanohalophilus zhilinae sp. Nov., an alkaliphili, halophilic, methylotrophic methanogen. Int J Syst Bacteriol 38:139-142.

McCollom TM (2008) Observational, experimental, and theoretical constraints on carbon cycling in Mid-Ocean Ridge hydrothermal systems. In: Magma to microbe: modeling hydrothermal processes at ocean spreading centers geophysical monograph series, vol 178, pp 193-213.

McCollom TM (2013) Laboratory simulations of abiotic hydrocarbon formation in Earth's deep subsurface. Rev Mineral Geochem 75:467-494.

McCollom TM, Bach W (2009) Thermodynamic constraints on hydrogen generation during serpentinization of ultramafic rocks. Geochim Cosmochim Acta 73:856-875.

McCollom TM, Sherwood Lollar B, Lacrampe-Couloume G, Seewald JS (2010) The influence of carbon source on abiotic organic synthesis and carbon isotope fractionation under hydrothermal conditions. Geochim Cosmochim Acta 74: $2717-2740$.

McDermott JM, Ono S, Tivey MK, Seewald JS, Shanks WC III, Solow AR (2015) Identification of sulfur sources and isotopic equilibria in submarine hotsprings using multiple sulfur isotopes. Geochimica et. Cosmochimica Acta 160:169-187. https://doi.org/10.1016/j.gca.2015.02.016.

Miyazaki J, Makabe A, Matsui Y, Ebina N, Tsutsumi S, Ishibashi J, Chen C, Kaneko S, Takai K, Kawagucci S (2017) WHATS-3: an improved flow-through multibottle fluid sampler for Deep-Sea Geofluid research. Front Earth Sci 5:45. https://doi.org/10.3389/feart.2017.00045.

Morono Y, Inagaki F (2010) Automatic Slide-Loader Fluorescence Microscope for Discriminative Enumeration of Subseafloor Life. Scientific Drilling 9:32-36. https://doi.org/10.5194/sd-9-32-2010.

Morono Y, Terada T, Kallmeyer J, Inagaki F (2013) An improved cell separation technique for marine subsurface sediments: applications for high-throughput analysis using flow cytometry and cell sorting. Environ Microbiol 2:28412849. https://doi.org/10.1111/1462-2920.12153.

Morono Y, Terada T, Masui N, Inagaki F (2009) Discriminative detection and enumeration of microbial life in marine subsurface sediments. The ISME Journal 3:503-511. https://doi.org/10.1038/ismej.2009.1. 
Mottl MJ, Komor SC, Fryer P, Moyer CL (2003) Deep-slab fluids fuel extremophilic archaea on a Mariana forearc serpentinite mud volcano: Ocean Drilling Program Leg 195. Geochem Geophys Geosyst 4:9009.

Mottl MJ, Wheat CG, Fryer P, Gharib J, Martin J (2004) Chemistry of springs across the Mariana forearc shows progressive devolatilization of the subduction plate. Geochim Cosmochim Acta 68:4915-4933.

Nakagawa S et al (2006) Microbial community in black rust exposed to hot ridge flank crustal fluids. Appl Environ Microbiol 72:6789-6799.

Nakamura K, Takai K (2014) Theoretical constraints of physical and chemical properties of hydrothermal fluids on variations in chemolithotrophic microbial communities in seafloor hydrothermal systems. Prog Earth Planet Sci 1:5.

Nigro LM, Harris K, Orcutt BN, Hyde A, Clayton-Luce S, Becker K, Teske A (2012) Microbial communities at the borehole observatory on the Costa Rica Rift flank (Ocean Drilling Program Hole 896A). Front Microbiol 3:232. https://doi. org/10.3389/fmicb.2012.00232.

Nunoura T, Takaki Y, Kazama H, Hirai M, Ashi J, Imachi H, Takai K (2012) Microbial diversity in deep-sea methane seep sediments presented by SSU rRNA gene tag sequencing. Microbes Environ 27:382-390. https://doi.org/10.1264/jsme2.ME12032.

Ohara Y et al (2012) A serpentinite-hosted ecosystem in the southern Mariana Forearc. Proc Natl Acad Sci U S A 109:2831-2835. https://doi.org/10.1073/ pnas.1112005109.

Okumura T, Kawagucci S, Saito Y, Matsui Y, Takai K, Imachi H (2016b) Hydrogen and carbon isotope systematics in hydrogenotrophic methanogenesis under $\mathrm{H}$ 2-limited and $\mathrm{H}$ 2-enriched conditions: implications for the origin of methane and its isotopic diagnosis. Prog Earth Planet Sci 3:14.

Okumura T et al (2016a) Brucite chimney formation and carbonate alteration at the Shinkai seep field, a serpentinite-hosted vent system in the southern Mariana forearc. Geochem Geophys Geosyst 17. https://doi.org/10.1002/ 2016GC006449.

Onishi Y, Yamanaka T, Okumura T, Kawagucci S, Watanabe HK, Ohara Y (2018) Evaluation of nutrient and energy sources of the deepest known serpentinite-hosted ecosystem using stable carbon, nitrogen, and sulfur isotopes. PLoS One 13(6):e0199000.

Orphan VJ, House CH, Hinrichs K-U, McKeegan KD, DeLong EF (2001) Methaneconsuming archaea revealed by directly coupled isotopic and phylogenetic analysis. Science 293:484-487.

Penning $H$, Plugge CM, Galand PE, Conrad R (2005) Variation of carbon isotope fractionation in hydrogenotrophic methanogenic microbial cultures and environmental samples at different energy status. Glob Chang Biol 11:2103-2113.

Pester NJ, Conrad ME, Knauss KG, DePaolo DJ (2018) Kinetics of D/H isotope fractionation between molecular hydrogen and water. Geochim Cosmochim Acta 242:191-212.

Proskurowski G, Lilley MD, Seewald JS, Fru h-Green GL, Olson EJ, Lupton JE, Sylva SP, Kelley DS (2008) Abiogenic Hydrocarbon Production at Lost City Hydrothermal Field. Science 319:604-607. https://doi.org/10.1126/science. 1151194.

Redfield AC (1958) The biological control of chemical factors in the environment. Am Sci 46:205-221.

Reeves E, Seewald JS, Sylva SP (2012) Hydrogen isotope exchange between n- alkanes and water under hydrothermal conditions. Geochim Cosmochim Acta 77:582-599.

Russell MJ et al (2014) The drive to life on wet and icy worlds. Astrobiology 14: 308-343.

Saegusa S, Tsunogai U, Nakagawa F, Kaneko S (2006) Development of a multibottle gas-tight fluid sampler WHATS II for Japanese submersibles/ROVs. Geofluids 6:234-240.

Sano Y, Marty B (1995) Origin of carbon in fumarolic gas from island arcs. Chem Geol 119:265-274.

Schrenk MO, Brazelton WJ, Lang SQ (2013) Serpentinization, carbon, and deep life. Rev Mineral Geochem 75:575-606.

Seewald JS, Doherty KW, Hammar TR, Liberatore SP (2001) A new gas-tight isobaric sampler for hydrothermal fluids. Deep Sea Res 49:189-196. https://doi.org/10.1016/S0967-0637(01)00046-2.

Seewald JS, Seyfried WE Jr, Shanks WC III (1994) Variations in the chemical and stable isotope composition of carbon and sulfur species during organic-rich sediment alteration: an experimental and theoretical study of hydrothermal activity at Guaymas Basin, Gulf of California. Geochim Cosmochim Acta 58: 5065-5082.
Sessions AL, Sylva SP, Summons RE, Hayes JM (2004) Isotopic exchange of carbon-bound hydrogen over geological timescales. Geochim Cosmochim Acta 68:1545-1559.

Seyfried WE Jr, Foustoukos DI, Fu Q (2007) Redox evolution and mass transfer during serpentinization: an experimental and theoretical study at $200{ }^{\circ} \mathrm{C}, 500$ bar with implications for ultramafic-hosted hydrothermal systems at MidOcean Ridge. Geochim Cosmochim Acta 71:3872-3886.

Seyfried WE Jr., Pester NJ, Ding K, Rough M (2011) Vent fluid chemistry of the Rainbow hydrothermal system ( $\left.36^{\circ} \mathrm{N}, \mathrm{MAR}\right)$ : Phase equilibria and in situ $\mathrm{pH}$ controls on subseafloor alteration processes. Geochimica et Cosmochimica Acta 75:1574-1593. https://doi.org/10.1016/j.gca.2011.01.001.

Shibuya T, Komiya T, Takai K, Maruyama S, Russell MJ (2017) Weak hydrotherma carbonation of the Ongeluk volcanics: evidence for low $\mathrm{CO} 2$ concentrations in seawater and atmosphere during the Paleoproterozoic global glaciation. Prog Earth Planet Sci 4:31. https://doi.org/10.1186/s40645-017-0145-6.

Sherwood Lollar B, Westgate TD, Ward JA, Slater GF, Lacrampe-Couloume G (2002) Abiogenic formation of alkanes in the Earth's crust as a minor source for global hydrocarbon reservoirs. Nature 416:522-524. https://doi.org/10. 1038/416522a.

Shipboard Sci. Party (2002) In: Peters LL (ed) Site 1200. Proc. Ocean Drill. Prog. Initial Rep., Vol. 195. Ocean Drill. Prog./Texas A\&M Univ, College Station. https://doi.org/10.2973/odp.proc.ir.195.103.2002.

Stern RJ, Ren M, Kelley KA, Ohara Y, Martinez F, Bloomer SH (2014) Basaltic volcaniclastics from the Challenger Deep forearc segment, Mariana convergent margin: Implications for tectonics and magmatism of the southernmost Izu-Bonin-Mariana arc. Island Arc 23:368-382. https://doi.org/ 10.1111/iar.12088.

Stolper DA, Lawson M, Davis CL, Ferreia AA, Santos Neto EV, Ellis GS, Lewan MD, Martini AM, Tang Y, Schoell M, Sessions AL, Eiler JM (2014) Formation temperatures of thermogenic and biogenic methane. Science 344:1500-1503.

Suda K, Ueno Y, Yoshizaki M, Nakamura H, Kurokawa K, Nishiyama E, Yoshino K, Hongoh Y, Kawachi K, Omori S, Yamada K, Yoshida N, Maruyama S (2014) Origin of methane in serpentinite-hosted hydrothermal systems: The $\mathrm{CH} 4$ $\mathrm{H} 2-\mathrm{H} 2 \mathrm{O}$ hydrogen isotope systematics of the Hakuba Happo hot spring. Earth and Planetary Science Letters 386:112-125. https://doi.org/10.1016/j. epsl.2013.11.001

Takai K, Gamo T, Tsunogai U, Nakayama N, Hirayama H, Nealson KH, Horikoshi K (2004) Geochemical and microbiological evidence for a hydrogen-based, hyperthermophilic subsurface lithoautotrophic microbial ecosystem (HyperSLiME) beneath as active deep-sea hydrothermal field. Extremophiles 8:269-282.

Takai K, Moser DP, Onstott TC, Spoelstra N, Pfiffner SM, Dohnalkova A, Fredrickson JK (2001) Alkaliphilus transvaalensis gen. nov., sp. Nov., an extremely alkaliphilic bacterium isolated from a deep South African gold mine. Int $J$ Syst Evol Microbiol 51:1245-1256.

Takai K, Moyer CL, Miyazaki M, Nogi Y, Hirayama H, Nealson KN, Horikoshi K (2005) Marinobacter alkaliphilus sp. Nov., a novel alkaliphilic bacterium isolated from subseafloor alkaline serpentine mud from Ocean Drilling Program Site 1200 at South Chamorro Seamount, Mariana Forearc. Extremophiles 9:17-27.

Takai K, Nakamura K, Suzuki K, Inagaki F, Nealson KH, Kumagai H (2006) Ultramafic-Hydrothermalism-Hydrogenesis-HyperSLiME (UltraH3) linkage: a key insight into early microbial ecosystem in the Archean deep-sea hydrothermal systems. Paleontological Res 10:269-282.

Takai K, Nakamura K, Toki T, Tsunogai U, Miyazaki M, Miyazaki J, Hirayama H, Nakagawa S, Nunoura T, Horikoshi K (2008) Cell proliferation at $122^{\circ} \mathrm{C}$ and isotopically heavy $\mathrm{CH} 4$ production by a hyperthermophilic methanogen under high-pressure cultivation. Proc Natl Acad Sci U S A 105:10949-10954.

Tishchenko P, Hensen C, Wallmann K, Wong CS (2005) Calculation of the stability and solubility of methane hydrate in seawater. Chem Geol 219:37-52.

Ueda H, Shibuya T, Sawaki Y, Saitoh M, Takai K, Maruyama S (2016) Reactions between komatiite and $\mathrm{CO} 2$-rich seawater at 250 and $350^{\circ} \mathrm{C}, 500$ bars: implications for hydrogen generation in the Hadean seafloor hydrothermal system. Progress in Earth and. Planet Sci 3:35. https://doi.org/10.1186/s40645-016-0111-8..

Valentine DL, Chidthaisong A, Rice A, Reeburgh WS, Tyler SC (2004) Carbon and hydrogen isotope fractionation by moderately thermophilic methanogens. Geochim Cosmochim Acta 68:1571-1590.

Wang DT, Gruen DS, Lollar BS, Hinrichs KU, Stewart LC, Holden JF, Hristov AN, Pohlman JW, Morrill PL, Konneke M, Delwiche KB, Reeves EP, Sutcliffe CN Ritter DJ, Seewald JS, McIntosh JC, Hemond HF, Kubo MD, Cardace D, 
Hoehler TM, Ono S (2015) Nonequilibrium clumped isotope signals in microbial methane. Science 348:428-431. https://doi.org/10.1126/science. aaa4326.

Wheat CG, Fryer P, Fisher AT, Hulme S, Jannasch H, Mottl MJ, Becker K (2008)

Borehole observations of fluid flow from South Chamorro Seamount, an active serpentinite mud volcano in the Mariana forearc. Earth Planet Sci Lett 267:401-409

Wiesenburg DA, Guinasso NL Jr (1979) Equilibrium solubilities of methane, carbon monoxide, and hydrogen in water and sea water. J Chem Eng Data 24:356-560.

\section{Submit your manuscript to a SpringerOpen ${ }^{\circ}$ journal and benefit from:}

- Convenient online submission

- Rigorous peer review

- Open access: articles freely available online

- High visibility within the field

- Retaining the copyright to your article

Submit your next manuscript at $\boldsymbol{\nabla}$ springeropen.com 